\title{
Análise Ética em Artigos Científicos que Envolvam Seres Humanos, no Período de 1990 - 1996
}

\section{SIMONE RIBEIRO SPINETTI}

Dissertação de Mestrado apresentada ao Departamento de Práticas de Saúde Pública da Faculdade de Saúde Pública da Universidade de São Paulo para obtenção do Título de Mestre

ORIENTADOR: PROF. DR. PAULO ANTONIO DE CARVALHO FORTES 
"Existem novas questões para a tarefa da ética. A reflexão filosófica e a prática pedagógica devem compor suas atribuições. Não devem ser apenas apanágio de uma categoria profissional ou de uma disciplina: é preciso o esforço e a conversação plural para melhor compreender e julgar. Não se trata de uma nova Burocracia, mas de um balizamento para uma Pedagogia."

Renato Sérgio Balão Cordeiro 


\section{Agradecimentos}

São tantas as pessoas que gostaria de agradecer, que não me perdoaria se esquecesse algum nome: Professor Paulo Fortes e Elma Zoboli não tenho palavras para exprimir a gratidão pelo inestimável apoio, boa vontade, amizade, incentivo, paciência, profissionalismo, Muito Obrigada! As minhas queridíssimas amigas: Daniele Sacardo, Sônia Matsuda e Bettina Gerken, pela grande e valiosa amizade que conquistamos no decorrer desta etapa de minha vida, e espero que estejam presentes em muitas outras, Muito Obrigada! A minha querida amiga e professora de Inglês, Teresa, pelas valiosas informações, paciência e carinho, Muito Obrigada! A querida Renilda, Marcinha, Cidinha do departamento de Pós Graduação, por terem sido tão boas, disponíveis, pacientes, Muito

Obrigada! A Ângela, Sílvia, Marilena da Secretaria de Pós Graduação, pelas informações pertinentes, pelo carinho e força, muito obrigada! As Secretárias do Departamento de Práticas, Cidinha e Regina, pelo carinho e apoio. Muito Obrigada! Pelos profissionais da Bibilioteca: Samuel, Maria Lúcia, Toninha, Carminha dentre outros que fizeram parte direta ou indireta neste trabalho, Muito Obrigada! Ao pessoal da xerox Marquinhos,

Carminha, Anderson(s), Léia, Dani e Angelino, pelos bons papos no balcão para descontrair de tantas tarefas, Muito Obrigada! A minha querida amiga

Dona Rosina, pela oportunidade ímpar, carinho e apoio em todo este processo, Muito Obrigada! E, obviamente, nunca me esqueceria dos meus queridos pais, Ney e Mário, pela paciência, incentivo, apoio financeiro, carinho, admiração, eu adoro e admiro um muito Vocês! Muito Obrigada! Aos meus queridos irmãos, especialmente as minhas irmãs Mirela, pela super paciência, carinho, dedicação, disponibilidade, e Elô, pelo interesse e incentivo, as cunhadas e meu cunhado e meus adoráveis e queridos sobrinhos. Muito Obrigada! E, a todas as outros funcionários da faculdade, professores, amigos, que de forma direta ou indireta contribuíram para com este trabalho. Peço desculpas se esqueci de citar algum nome, é a emoção de relembrar tantos fatos!!! Mesmo assim, aceitem todos o meu

\section{Muito Obrigada!!!!}




\section{Resumo}

O presente estudo teve como objetivo analisar artigos científicos na área de saúde pública, que envolviam direta e indiretamente seres humanos, publicados anteriormente à Resolução 196/96. Analisamos artigos científicos da Revista de Saúde Pública e Cadernos de Saúde Pública de 1990 a 1996. Baseamos nossa análise em categorias retiradas da Resolução 196/96 previamente estabelecidas: consentimento do sujeito de Pesquisa, sujeitos com autonomia reduzida, proteção de sujeitos e grupos vulneráveis e legalmente incapazes, confidencialidade, privacidade, proteção da imagem, estigmatização, benefícios do retorno da pesquisa. A análise dos dados foi efetuada em dois momentos: caracterização das revistas analisadas e análise de conteúdo. Os resultados encontrados foram: 568 artigos levantados, 384 (67,6\%) da Revista da Saúde Pública e 184 (32,4\%) dos Cadernos de Saúde Pública. Destes, 296 (52,1\%) envolviam direta ou indiretamente sujeitos humanos que foram objeto de nossa análise. Instituições mais utilizadas para o desenvolvimento de pesquisas: serviços de saúde 134 (23,6\%), empresas, indústrias, escritórios e instituições públicas 52 (9,2\%), residências $42(7,4)$, lazer e assistência social somam 6 (10\%). Tipos de pesquisa: epidemiológica 121 (21,3\%), biológica 59 (10,4\%), psicológica 10 (1,8\%), nutricional 42 (7,4\%), ambiental 9 (1,6\%). Analisamos qualitativamente trechos de artigos baseando nossa análise na Resolução 196/96. Consideramos que antes da elaboração da resolução 196/95, talvez não existisse um interesse 


\section{SUMMARY}

Spinetti SR. Analysis on scientific Articles from an Ethical Point of View involving Human Beings from 1990-1996. [Articles from the periodicals "Revista de Saúde Pública" and "Cadernos de Saúde Pública" were analysed from 1990 through 1996]. São Paulo (BR); 1998. [Dissertation of Master Faculdade de Saúde Pública and Universidade de São Paulo].

The present study objective is analyse the scientific articles in the public health area, involving human beings directly and indirectly, published prior to the enforcement of Resolution 196/96. [It was researched all the published articles in the Revista de Saúde Pública and Cadernos de Saúde Pública Journals from 1990 to 1996]. The articles were analysed based on categories previously established by Resolution 196/96: subjects consent, subjects with little autonomy, protection of vulnerable and legally incapable groups, confidentiality, privacy, protection of the image, stigma, benefits, social return of the research. The analysis were divided in two moments: $1^{\text {st }}$ moment: caractherization of the two periodicals and $2^{\text {nd }}$ moment, qualitative analysis of the articles content analysis. The results were as follows: 568 scientific articles, 384 (67,6\%) from Revista de Saúde Pública and 184 (32,4\%) from Cadernos de Saúde Pública. Of these, 296 (52,1\%) involved human beings direct or indirectly and that was the objective of the analysis. The institutions used for research: The health system 134 (23,6\%); industries, offices and state institutions 52 (9,2\%); residences 42 (7,4\%), places of leisure and social services added 6 (10\%). Type of research: Epidemiological 121 $(21,3 \%)$, biological $59(10,4 \%)$, psichological $10(1,8 \%)$, nutritional $42(7,4 \%)$, ambiental $21(3,7 \%)$, social $20(3,5 \%)$, services and programs evaluation 9 $(1,6 \%)$. Extracts from articles were analysed qualitatively based on the Resolution 196/96. Bearing in mind that at the time of such publication $1990 / 1996$ the concept of giving explanatory approach to the subject of research were not common practice, but with the enforcement of the Resolution this culture is being gradually changed. 


\section{Índice}

1. Introdução

\section{Índice}

Paginação

1.1. A Importância da Ética em Pesquisa 9

1.2. Seleção de Sujeitos de Pesquisa $\quad 12$

1.3. Metodologia 13

1.4. Pesquisa na Área de Saúde Pública $\quad 15$

1.5. Histórico da Ética em Pesquisa na Área de Saúde 18

$\begin{array}{ll}\text { 1.5.1. Código de Nuremberg } & 18\end{array}$

1.5.2. Declaração de Helsinque 20

1.5.3. Relatório de Belmont 23

1.5.4. Normas Éticas Internacionais paras as Investigações 27 Biomédicas com Sujeitos Humanos - CIOMS/OMS

1.5.5. Guia Internacional para Análise Ética de Estudos 29 Epidemiológicos

1.5.6. Resoluções sobre Ética em Pesquisa em Alguns Países 31 do Mundo

1.6. Ética em Pesquisa no Brasil 33

1.6.1. Resolução 01/88 33

1.6.2. Resolução 196/96 36

1.6.3. Resolução 251/97 40

2. Objetivo 44

3. Metodologia 46

3.1. Tipo de Pesquisa $\quad 46$

3.2. Pré-Teste 48

3.3. Critérios de Seleção $\quad 48$

3.4. Coleta de Dados $\quad 49$

3.5. Instrumental para Coleta de Dados $\quad 49$

3.6. Análise dos Dados 53

3.7. Considerações Éticas $\quad 53$

4. Resultados e Discussão 55

4.1. Caracterização da Amostra 56

5. Autonomia e Consentimento 60

5.1. idosos $\quad 68$

5.2. Sujeitos de Pesquisa com Competência Reduzida 70

$\begin{array}{ll}\text { 5.2.1. Crianças e Adolescentes } & 70\end{array}$

$\begin{array}{ll}\text { 5.2.2. Pessoas com Transtornos Mentais } & 74\end{array}$

6. Sujeitos de Pesquisa em Situação de Vulnerabilidade 76 
6.1. Sujeitos Expostos à Condicionamentos Específicos ou à 78 Influência de Autoridade

6.2. Empregados 83

6.3. Prisioneiros e Menores Institucionalizados 86

7. Comunidades Culturalmente Diferenciadas Inclusive 88 indígenas

8. Confidencialidade - Privacidade - Proteção de Imagem e 94 Não Estigmatização

8.1. Pesquisas utilizando Dados Secundários 98

9. Análise do Retorno dos Benefícios decorrentes da 102 Pesquisa

9.1. Benefícios Diretos aos Sujeitos de Pesquisa 104

9.2. Retorno da Pesquisa: Institucional e Social 106

10. Considerações Gerais 112

$\begin{array}{ll}\text { Referências Bibliográficas } & 115\end{array}$

$\begin{array}{ll}\text { Anexo } 1 & 123\end{array}$

$\begin{array}{ll}\text { Anexo } 2 & 126\end{array}$ 
Introdução 
Atualmente muito tem sido discutido sobre ética em pesquisa envolvendo seres humanos. O interesse sobre o assunto tem-se convertido em vários artigos e publicações sobre o tema com autoria de profissionais de diversas áreas de atuação, bem como, discussões e a elaboração de códigos, diretrizes e normas éticas voltadas às pesquisas que envolvam direta ou indiretamente seres humanos.

Para uma melhor compreensão sobre a questão, faremos um breve relato sobre o tema.

\subsection{A Importância da Ética em Pesquisa}

O conceito de pesquisa é muito amplo, mas a característica básica do seu campo de atuação é produzir conhecimento que possa trazer tanto benefícios diretos como indiretos à sociedade (retorno à sociedade através de programas e práticas, bem como, através de publicações científicas, seminários e ensinamentos em geral). É a busca de conhecimentos que possam nortear ações em diferentes áreas de atuação buscando a solução e o entendimento de questões de diversas naturezas.

GIL (1994), define pesquisa como “... processo formal e sistemático de desenvolvimento do método científico. O objetivo fundamental da pesquisa è descobrir respostas para problemas mediante o emprego de procedimentos científicos." (p.43)

Por sua vez STEVENSON et col. (1993) a definem de uma forma peculiar, entendendo-a, como o : "fazer a coisa certa é o que a sociedade espera dos cientistas, cuja pesquisa deve ser conduzida para aprimorar a qualidade de vida." (p.19) 
Para FORATTINI (1995), pesquisa:

“... trata de atividade mediante a qual visa-se a adquirir conhecimentos que possibilitem a compreensão dos fenômenos físicos, biológicos e sociais, incluindo os concernentes aos próprio homem, como indivíduo ..., o que caracteriza a atividade de pesquisa vem a ser a permanente busca de soluções, de idéias e de fatos e de formulação de hipóteses explicativas, bem como o encontro de conhecimentos passíveis de serem tecnologicamente utilizáveis na melhora constante da qualidade de vida do homem." (p.82)

A Resolução 196/96 do Conselho Nacional de Saúde - Ministério da Saúde, a qual regulamenta as pesquisas com seres humanos no Brasil define pesquisa como:

“... - classe de atividades cujo objetivo é desenvolver ou contribuir para o conhecimento generalizável. O conhecimento generalizável consiste em teorias, relações ou princípios ou no acúmulo de informações sobre as quais estão baseadas, que possam ser corroboradas por métodos científicos aceitos de observação e inferência." (p.5)

Pesquisas podem envolver seres humanos, individual ou coletivamente, direta ou indiretamente, de maneira invasiva ou não invasiva, através de abordagem direta ao participante da pesquisa, análise de material biológico coletado ou utilização de dados secundários.

Podemos perceber que para a maioria dos autores citados a pesquisa busca novos conhecimentos visando a melhoria da qualidade de vida. Partindo dessa premissa, coloca-se a questão de até que ponto esta busca por qualidade de vida pode afetar sujeitos de pesquisa em nome da ciência. 
O desejo de testar para produzir conhecimento muitas vezes tem levado pesquisadores a utilizarem seres humanos como um meio de conseguir comprovar as hipóteses e os objetivos formulados, sem considerar contudo, o impacto que o processo da pesquisa possa causar às pessoas envolvidas como sujeitos de pesquisa, tais como: os danos físicos, psicossociais e morais. Por isso, deve-se criar mecanismos de salvaguarda para evitar os abusos da experimentação e a "cobaização" do ser humano. (HOSSNE e VIEIRA 1995).

Sendo assim, a reflexão sobre ética na pesquisa surge objetivando garantir direitos básicos aos seres humanos, sujeitos de pesquisa, como uma necessidade social de resgatar e defender valores que venham a preservar o homem e impeçam ações maleficentes colocando em risco os participantes e violando sua autonomia e seus direitos. Através destas ações práticas, a ética em pesquisa busca um relacionamento mais interativo e digno entre pesquisador e sujeito da pesquisa, visando assim, uma pesquisa de maior qualidade cientifica e humana.

STEVENSON e col. (1993) reflete muito bem esta questão quando considera:

"É certo que a necessidade de extensivos estudos empíricos sobre ética é imperativo. Além disso, não devemos esquecer que o dilema ético em pesquisa é apresentado pela cultura, sexo e diferenças geográficas. Um relacionamento colaborativo entre investigadores e a comunidade de interesse contribuirá significantemente com a ética em pesquisa." (p.48)

Para o desenvolvimento de pesquisas éticas devemos nos ater na importância da escolha do sujeito de pesquisa e da metodologia que será empregada na mesma. 


\subsection{Seleção de Sujeitos de Pesquisa}

Quem é o sujeito de pesquisa? A Resolução 196/96, coloca que sujeito de pesquisa é o (a) participante pesquisado(a), individual ou coletivamente, de caráter voluntário, vedada qualquer forma de remuneração. (p.6)

Como escolher o sujeito de pesquisa? Consideramos que a escolha do sujeito de pesquisa tenha relação direta com a prática ética da pesquisa. Para tanto, coloca PORTER (1989), a seleção de sujeitos deve ser cuidadosamente revista para determinar se algumas classes estão sendo sistematicamente selecionadas, geralmente devido a sua disponibilidade ou manipulação.

Frente ao exposto acima, verificamos que deva existir, antes de mais nada, o respeito à autonomia do indivíduo, reconhecendo suas capacidades e expectativas, incluindo seu direito a ter determinadas idéias e a tomar determinadas decisões. E ainda assim, não se deve criar obstáculos com relação a suas ações, a menos que estas ações atentem claramente contra outras pessoas. (LaVERTU e LINHARES 1990)

As resoluções sobre ética em pesquisa e diversos autores interessados no tema propõem elementos para seleção de sujeitos de pesquisa. Neste sentido, expomos o enunciado pela UNAIDS (2000), a qual sugere que a seleção de sujeitos de pesquisa deverá ser baseada na relevância do sujeito da pesquisa com o tema em estudo. Afirmam ainda, que o protocolo de pesquisa deverá: justificar a seleção dos sujeitos de pesquisa através de pontos de vista científicos; pontuar quais são os possíveis riscos e se os mesmos estão contrabalanceados com os potenciais benefícios; estabelecer mecanismos de proteção para os sujeitos de pesquisa de potenciais danos relativos à pesquisa. 
Pesquisas na área de saúde pública e epidemiologia, lidam, com maior número de sujeitos de pesquisa, apesar de não ser um regra, tornando-se importante que estes sujeitos sejam recrutados de forma eqüitativa, dando oportunidade para que todos se apresentem para participar.

Neste sentido, CIOMS (1996) coloca em seu capítulo sobre distribuição eqüitativa de cargas e benefícios, que se uma pesquisa touxer benefícios vantajosos aos sujeitos participantes, talvez seja procedente neste caso fazer uma ampla publicidade dando oportunidade de participação na investigação ou de estabelecer programas de divulgação para indivíduos ou grupos que não consigam facilmente informações sobre os programas de investigação.

Outro fator que afeta a escolha e utilização dos sujeitos de pesquisa é a metodologia. A metodologia possui relação direta com a ética em pesquisa. Sobre este tema explanaremos à seguir.

\subsection{Metodologia}

Uma metodologia adequada e bem suportada é imprescindível para o desenvolvimento de uma pesquisa ética.

A Resolução 196/96, expressa que toda pesquisa deverá obedecer à metodologia adequada. Se houver necessidade de distribuição aleatória dos sujeitos da pesquisa em grupos experimentais e de controle, assegurar que, a priori, não seja possível estabelecer as vantagens de um procedimento sobre o outro através de revisão de literatura, métodos observacionais ou métodos que não envolvam seres humanos.

HOOSNE e VIEIRA (1995) afirmam que os experimentos com seres humanos devem ser planejados da melhor maneira possível. Não é justo 
expor pacientes ao desconforto e à inconveniência, além de possíveis danos, sem que disso resulte benefício real para a Sociedade.

Entendemos, então, que no caso de uma metodologia inadequada, ocorre a utilização indevida de sujeitos de pesquisa, mau uso de financiamentos públicos ou privados, desperdício de tempo, e desgaste por parte do pesquisador e dos participantes, para uma pesquisa cujo produto final não trará nenhum tipo de benefício direto e indireto.

PEARSON et al (1998) afirmam, que o principal imperativo ético é integrar na metodologia, sistemas de segurança, para que se possa minimizar o máximo possível os conflitos.

A investigação da pesquisa está valorativamente inserida numa política de transformação, além de intimamente relacionada com o tipo de proposta e os "atores" considerados. Revela-se que toda estratégia de pesquisa possui alguns critérios de orientação valorativa. A moralidade da pesquisa vai depender da moralidade da ação considerada e dos meios de investigação utilizados. SOLDATI (1997)

Para finalizar FORTES (1999) afirma que os Comitês de Ética em Pesquisa devem observar, no delineamento dos projetos de pesquisa, se os procedimentos metodológicos possibilitam que todas as pessoas sejam sujeitos de pesquisa e beneficiários de seus resultantes proveitosos.

\subsection{Pesquisa na Área de Saúde Pública}

A pesquisa na área de saúde pública busca estudar os problemas que atingem a população no seu caráter coletivo, com o propósito de alcançar os melhores objetivos propostos e que venham a beneficiar grande parte da população, contribuindo, de alguma forma com o bem estar do ser humano. 
A importância da pesquisa na área de saúde pública é caracterizada pela sua abrangência e diversidade, seu caráter multiprofissional e a importância de sua atuação no contexto sócio-econômico.

Para SCUTCHFIELD e KECK (1996) a saúde pública deve aplicar os conhecimentos adquiridos para a melhoria da saúde de grupos/comunidades, através da promoção da saúde de prevenção de doenças.

SHEPS e RIDLEY (1964) afirmam que a saúde pública possui o propósito de abranger todas as ciências que produzem saúde humana, buscando relações vantajosas e um enriquecimento mútuo, tendo como propósito principal ações nesta área.

Para John Last citado por SCUTCHFIELD e KECK (1996 p. 73) a saúde pública é:

"... um dos esforços organizados pela sociedade para proteger, promover e restaurar a saúde das pessoas. É uma combinação de ciência, habilidades e opiniões que são direcionadas para a manutenção e melhoria da saúde de todas as pessoas através de ações coletivas ou sociais ... a ação da saúde pública muda com as mudanças da tecnologia e valores sociais, mais as metas permanecem as mesmas: reduzir doenças, mortes prematuras, doenças desconfortáveis e incapacidades na população."

A pesquisa na área de saúde pública é muito ampla, podendo abranger planejamento de serviços em saúde comunitária, organização, deliberação e custos e serviços individuais de saúde, danos ambientais, controle de doenças crônicas, controle do tabagismo, álcool e drogas, controle de doenças infeciosas, proteção da saúde ambiental, cuidados 
primários, saúde materno-infantil, controle de acidentes, saúde mental, violência entre outros temas.

Várias são as disciplinas que permeiam as pesquisas e a prática em saúde pública. WILNER et col (1978) afirmam que a saúde pública possui uma abordagem interdisciplinar, mais que o campo tradicional associado à saúde pública inclui a epidemiologia, bioestatística, medicina preventiva, enfermagem, administração em saúde e de cuidados de saúde, sendo complementada pela saúde ambiental numa abordagem de grande importância em nosso contexto atual.

WILNER et col (1978) reconhecem que com o aumento das ações nesta área, torna-se necessário incorporar o conhecimento de outras disciplinas tais como: economia, política e ciências do comportamento: antropologia, psicologia social e particularmente a sociologia. Cabe ressaltar, que tais disciplinas atualmente já estão incorporadas na saúde pública e são de fundamental importância nas pesquisas na área incorporando também, disciplinas como: nutrição, agronomia e mais recentemente a ética que vem ganhando espaço nesta área de atuação.

Somente para elucidar a questão da pesquisa na área de saúde pública, salientamos FORATTINI (1995):

“... as atividades no campo da saúde pública são caracteristicamente multidisciplinares, entendendo-se com isso, o imprescindível concurso de variadas áreas de estudo. Depreende-se daí que a pesquisa científica deverá ser levada a efeito em múltiplos campos do conhecimento, isto é, nas mais variadas especialidades. De maneira geral, os fatores determinantes dos agravos à saúde populacional podem ser sistematizados em três categorias, a físicoquímica, a biológica e a social, obviamente inter-relacionadas. Esse entrelaçamento de informações levará ao entendimento do 
mecanismo gerador e sustentador da problemática que afeta a população."(p.85)

FORATTINI (1995) complementa que todos os esforços efetuados pelas disciplinas que atuam em pesquisa na área de saúde pública têm como principal interesse a busca de melhorias na qualidade de vida.

Neste sentido, DEGRAVE (1999) afirma que a ciência tem como objetivo a construção de um modelo consciente, abrangente e unificado do Universo e sua evolução a partir de fenômenos observados ou postulados, a verificação do(s) modelo(s) simulados da "realidade", construir previsões sobre fenômenos futuros, e transformar o conhecimento em progresso tecnológico e melhoria da qualidade de vida do ser humano. A ciência, continua o autor, vive uma delicada situação entre o ímpeto de buscar o conhecimento, e a expectativa de transformar esse conhecimento em aplicações práticas e úteis para a sociedade.

Faz-se relevante voltar nosso olhar para as pesquisas em saúde pública, devido à sua grande importância, principalmente em países em desenvolvimento, a qual caracteriza nosso contexto sócio-econômico, refletindo em suas ações multidisciplinares o envolvimento de indivíduos, grupos e/ou comunidades vulneráveis visando com estas ações um retorno com justiça, eqüidade e em qualidade de vida para a sociedade.

Um breve histórico da ética em pesquisa no contexto internacional e nacional reforçará a discussão e reflexão sobre este tema, e sua importância na área de saúde. 


\subsection{Histórico da Ética em Pesquisa na Área de Saúde}

\subsubsection{Código de Nuremberg}

A discussão da ética em pesquisa envolvendo seres humanos remonta a antigüidade, mas seu grande marco foi há pouco mais de 50 anos, exatamente em 1946, após a constatação da prática de cruéis experimentos com prisioneiros de guerra, durante a Segunda Guerra Mundial, cuja indignação resultou na elaboração do primeiro Código de Experimentação em Seres Humanos - Código de Nuremberg.

"Todos os experimentos foram conduzidos com sofrimento e ferimentos desnecessários e, poucos cuidados foram tomados para proteger ou salvaguardar os sujeitos humanos das possibilidades de danos, incapacidade ou morte. Em todos os experimentos os sujeitos experimentaram extrema dor ou tortura, e muitos deles sofreram danos permanentes, mutilações ou mortes como resultado direto dos experimentos ou devido a falta de cuidados adequados." (KENNEDY 1989, p.863).

O Código de Nuremberg enfatiza que as pesquisas devem trazer relevância social, bem como, evoca a autonomia do pesquisado através de informações sobre os procedimentos da pesquisa que possam conduzir à manifestação de seu consentimento voluntário em participar.

Ainda sobre o Código de Nuremberg é interessante citar FORTES (1998):

"O documento afirma que toda a experiência científica deve ter como objetivo o bem da sociedade, tendo em vista, resultados práticos que não possam ser obtidos por outros meios. Evoca a condição autonômica das pessoas que se prestem a pesquisas, enfatizando a 
essencialidade da informação, e do recolhimento do consentimento voluntário." (p.106)

Faz-se imprescindível entender qual a dimensão do termo "consentimento voluntário", sendo o mesmo utilizado em diversos códigos e resoluções éticas de grande importância em todo o mundo. Para tanto, citamos, qual o significado do consentimento voluntário, conforme o Código de Nuremberg:

"O consentimento voluntário do ser humano é absolutamente essencial. Isso significa que as pessoas que serão submetidas ao experimento devem ser legalmente capazes para dar consentimento; essas pessoas devem exercer o livre direito de escolha sem qualquer intervenção de elemento de força, fraude, mentira, coação, astúcia ou outra forma de restrição ou coerção posterior; devem ter conhecimento suficiente do assunto em estudo para tomarem a decisão. Esse último aspecto exige que sejam explicados às pessoas a natureza, duração e o propósito do experimento; os métodos segundo os quais será conduzido; as inconveniências e os riscos esperados; os efeitos sobre a saúde ou sobre a pessoa do participante, que eventualmente possa ocorrer, devido à participação no experimento." (VIEIRA e HOOSNE 1996 p. 112)

NEVES (2000) em seu relato sobre a "Declaração de Direitos Humanos" afirma que o Código de Nuremberg que constitue o testemunho de uma nova mentalidade emergente e veículo de sensibilização de uma mais profunda consciência individual e coletiva indispensáveis para o seu desenvolvimento. (p.215)

Ainda assim, conforme cita HOSSNE e VIEIRA (1995) “.... após o aparecimento do Código de Nuremberg, não obstante a dramaticidade do contexto em que nasceu, as infrações éticas, infelizmente, continuaram e continuam a acontecer." (p.129). 


\subsubsection{Declaração de Helsinque}

O grande aumento das pesquisas com seres humanos e a não condução satisfatória das mesmas do ponto de vista ético, apesar da influência do Código de Nuremberg, fez com que a Associação Médica Mundial, em 1964, durante a $18^{\mathrm{a}}$. Assembléia, em Helsinque, Finlândia, revisse e suplementasse as diretrizes do Código de Nuremberg. Disto originou a Declaração de Helsinque voltada às pesquisas biomédicas.

Esta Declaração trouxe grandes avanços na área da ética em pesquisa com seres humanos e tem sido utilizada como referencial por vários países que não possuem suas próprias diretrizes éticas para o desenvolvimento de pesquisas que envolvam direta ou indiretamente seres humanos.

Sua grande contribuição foram recomendações que ampliaram o Código de Nuremberg, adicionando em seu conteúdo a importância do consentimento pós informado, no qual o sujeito de pesquisa, após ser informado sobre os procedimentos da mesma, consente ou não em estar participando, trata das pesquisas que envolvam crianças, pessoas com distúrbios mentais ou de comportamento, mulheres grávidas, para que haja uma reflexão crítica do pesquisador com relação a escolha destes participantes, ou seja, somente sejam recrutados quando a pesquisas forem diretamente relacionada à problemática destes sujeitos, e ainda, o sigilo e confidencialidade das informações obtidas durante a pesquisa, e que as pesquisas tragam acima de tudo melhorias dos procedimentos diagnósticos e profiláticos sendo que os interesses concernentes ao ser humano devam sempre prevalecer sobre os interesses da ciência e da sociedade.

A Declaração de Helsinque sofreu diversas revisões e emendas. A primeira foi em 1975 - 29a . Assembléia Médica Mundial, em Tóquio, Japão, quando verificou-se a necessidade da criação de comitês de ética em 
pesquisa, cujo propósito seria aprovar os protocolos e acompanhar as pesquisas que estavam sendo realizadas; em 1983 - 35a. Assembléia Médica Mundial em Veneza, Itália; $1989-41^{\text {a }}$. Assembléia Médica Mundial em Hong Kong; 1996 - 48 . Assembléia Geral, em Somerset West, República da África do Sul, e mais recentemente a $52^{\mathrm{a}}$ Assembléia da Associação Médica Mundial, realizada em Edinburgo, Escócia de 3 a 7 de outubro de 2000.

Na versão elaborada na $48^{\mathrm{a}}$ Assembléia Geral na África do Sul, alguns pontos importantes foram discutidos e incorporados à Declaração, dentre eles podemos citar a preocupação para que pesquisas não afetem o meio ambiente e o bem estar dos animais, e a obrigação do pais hospedeiro e patrocinador com relação aos riscos e benefícios e retorno da pesquisa à população estudada. Na última versão, aprovada durante a $52^{a}$ Assembléia da Associação Médica Mundial, em Edinburgo, todas as modificações incorporadas, foram resultados de várias discussões e sugestões de diversos órgãos, associações e sociedade em geral, enfocando, principalmente, as pesquisas em países em desenvolvimento, e o retorno dos benefícios das mesmas aos sujeitos/comunidades estudadas.

Estas discussões foram geradas devido pesquisas efetuadas em mulheres gestantes sobre a transmissão vertical da AIDS, que foram desenvolvidas em diversos países da África do Sul e Ásia, países considerados sub-desenvolvidos, onde grande parte da população é considerada vulnerável. Por ser a Declaração de Helsinque, um documento reconhecido internacionalmente, base para pesquisas em diversos países, alguns pesquisadores, interessados no desenvolvimento da pesquisa nestes países, sugeriram mudanças no documento para que se tornasse mais simples a condução de mesmas, outros em contrapartida, afirmavam que deveria se manter o texto original da Declaração de Helsinque, garantindo assim, o menor risco pelo maior benefício dos sujeitos de pesquisa. 
Frente toda esta polêmica, as principais modificações na Declaração de Helsinque, discutidas por profissionais médicos do mundo inteiro durante a $52^{\text {a }}$ Assembléia da Associação Médica Mundial, foram as seguintes:

Na $48^{\mathrm{a}}$ Revisão da Declaração de Hensique em seu artigo II, sobre pesquisa médica combinada com cuidados profissionais (Pesquisa clínica) trazia o seguinte texto: "...deve-se ter assegurados o melhor método comprovado de diagnóstico e terapêutica". O atual texto da Declaração de Helsinque, discutido na $52^{\mathrm{a}}$ Assembléia Médica Mundial, no seu parágrafo 30: "No final do estudo, todos os pacientes participantes devem ter assegurados 0 acesso aos melhores métodos comprovados profiláticos, diagnósticos e terapêuticos identificados no estudo". Com relação ao uso de placebo, o texto da Declaração de Helsinque - $48^{\mathrm{a}}$ Assembléia Médica Mundial, trazia em sua Seção II.3: "Isto não exclui o uso de placebo inerte em estudos onde métodos diagnósticos ou terapêuticos não existam", e o atual texto da $52^{\mathrm{a}}$ Assembléia Médica Mundial coloca: "Os benefícios, riscos, dificuldades e efetividade de um novo método devem ser testados comparando-os com os melhores métodos profiláticos, diagnósticos e terapêuticos atuais. Isto não exclui o uso de placebo ou nenhum tratamento em estudos onde não existam métodos provados de profilaxia, diagnóstico ou tratamento."

Assim, conforme conclui GRECCO (2000) se as exigências éticas forem diminuídas será muito difícil sua recuperação futura, e torna-se necessário lutar para que haja acesso universal à saúde e educação e não considerar o status quo de disparidade como fato consumado.

Mesmo após elaboração do Código de Nuremberg e da Declaração de Helsinque, sujeitos de pesquisa têm sido passíveis de condutas antiéticas antes e no decorrer da elaboração destes dois importantes documentos. 
Frente a todo este movimento da ética em pesquisa, e o interesse crescente de diversos profissionais da área de pesquisa, outros documentos sobre o tema começaram a ser elaborados.

\subsubsection{Relatório Belmont}

Para ilustrar estas condutas, citamos uma pesquisa que foi desenvolvida nos Estados Unidos, chocando o mundo devido a sua perversidade. Apesar de ter sido um estudo muito famoso, infelizmente tem sido lembrado pela atitude medonha de seus autores.

O estudo de Tuskgee como é conhecido, foi realizado entre 1932 a 1972, e tinha como objetivo conhecer a história natural da sífilis. Foram selecionados para o estudo negros, pobres, agricultores da região de Tuskgee nos Estados Unidos. Os sujeitos da pesquisa eram selecionados por uma enfermeira negra, o que denotava uma maior confiabilidade e facilidade de indução a participar. Para que houvesse uma maior adesão ao estudo, a mesma recrutava os sujeitos alegando que os participantes receberiam tratamento gratuito. Mesmo com o advento da penicilina em 1940, nenhum destes sujeitos foi tratado. Foram utilizados 408 pacientes, sendo que 192 foram utilizados como controle. Este estudo somente teve seu fim em 1972, quando foi denunciado por uma jornalista da imprensa leiga. (HOOSNE e VIEIRA1998)

Mas, este estudo não foi um caso isolado na história dos Estados Unidos. Henry Beecher, médico anestesista americano, fez um estudo na década de 60 e constatou que mais de 50 pesquisas desenvolvidas nos Estados Unidos estavam sendo realizadas sem nenhuma conduta ética, usando sujeitos de pesquisas como cobaias em nome da ciência. (BEECHER 1966) 
Mediante o contexto apresentado profissionais da área de saúde e pessoas interessadas sobre o tema discutiram e elaboraram o Relatório de Belmont. O relatório foi assinado em 12 de julho de 1974 o Ato Nacional de Pesquisa (Lei Pública No. 93348) pelo Departamento de Saúde, Educação e Bem Estar - Escritório da Secretaria de Proteção dos Sujeitos Humanos, criando a Comissão Nacional para a Proteção de Sujeitos Humanos em Pesquisas Biomédicas e de Comportamento. Neste documento foram identificados princípios éticos básicos que deveriam sustentar pesquisas biomédicas e de comportamento e que envolvessem seres humanos.

"O Relatório Belmont - Princípios Éticos e Diretrizes para a Proteção dos Sujeitos Humanos de Pesquisa" foi o resultado dos trabalhos da Comissão que estabeleceu como princípios éticos básicos: Respeito às pessoas, beneficência, e justiça." (BELMONT REPORT 1974, p.1). O mesmo considera que pesquisa e prática devem ser desenvolvidas juntas, quando a pesquisa é designada para avaliar a segurança e eficácia de uma terapia, onde é imprescindível assegurar a proteção de seres humanos.

Foram considerados três princípios básicos que são considerados particularmente relevantes para a conduta ética em pesquisas envolvendo seres humanos: respeito pelas pessoas; justiça e beneficência. (BELMONT REPORT 1974, p.1)

Respeito pelas pessoas, basicamente engloba duas questões éticas básicas, ou seja: (i) indivíduos devem ser tratados como agentes autônomos, onde haja o respeito à pessoa, informação e voluntariado; (ii) respeito às pessoas com autonomia reduzida, ou seja, na perda de sua capacidade, no todo ou em parte, por motivo de doença, debilidade ou situações de severa restrição de liberdade, a incapacidade do indivíduo tem que ser protegida. (V.S. Department of Health, Education and Welfare 1974) 
Beneficência, é entendida como uma obrigação, estando a mesma relacionada com: (i) não causar danos; (ii) maximizar possíveis benefícios, e minimizar possíveis danos, esforçando-se ao máximo para garantir seu bem estar.

Justiça, expõe a questão da "distribuição justa "ou "quem merece?", levantando outras questões como: "iguais devem ser tratados igualmente?", "Quem é igual e quem é desigual?" Neste contexto, a Comissão chegou a conclusão que existem várias formulações aceitáveis de maneiras justas de distribuir responsabilidades e benefícios, sendo necessário explicar como será desenvolvida a pesquisa e que as pessoas deverão sempre serem tratadas igualmente.

Outra questão relevante considerada pelo Relatório Belmont é que como as pesquisas são desenvolvidas, na sua grande maioria, através de financiamentos públicos, coloca-se a prioridade de retorno dos resultados aos que necessitam, não somente para os que podem pagar pelos resultados obtidos e que não haja o envolvimento de pessoas e/ou grupos em pesquisas cujo retorno, provavelmente não estará entre os benefícios diretos à esses sujeitos.

Em breve resumo consideramos que o Código de Nuremberg e a Declaração de Helsinque já incorporavam de forma implícita as diretrizes da autonomia, beneficência e justiça, que foram explicitamente colocadas no Relatório Belmont.

A maioria dos códigos, diretrizes, resoluções e até mesmo leis que atualmente estabelecem condutas éticas para pesquisas com seres humanos utilizam as diretrizes contidas no relatório Belmont: respeito às pessoas, beneficência e justiça, como referencial para suas condutas éticas. 
BEAUCHAMP e CHILDRESS (1989), no seu livro "Princípios da Ética Biomédica", fazem uma grande contribuição ao dissertarem sobre o referencial principialista de condutas em pesquisas que envolvam seres humanos, sendo muito utilizado para ações éticas na área médica e biomédica em geral. Abaixo, fazemos um breve apanhado do referencial principialista que emgloba: autonomia, beneficência, não-maleficência e justiça.

Autonomia: É o auto reger-se, auto governar-se, de fazer escolhas individuais, liberdade de seguir sua própria vontade, tendo um comportamento próprio e sendo você mesmo.

Pessoas com capacidade diminuída de autonomia, tem sua autonomia controlada por outros ou são incapazes de deliberar ou agir com base em seus planos. Por exemplo: pessoas institucionalizadas, tais como, prisioneiros que estão passando por uma restrição social o que limita a sua autonomia, ou pessoas mentalmente retardadas, que devido a incapacidade psicológica possuem autonomia reduzida.

O consentimento informado é baseado na autonomia dos sujeitos da pesquisa, refere-se a decisão voluntária ou à concordância sobre as informações recebidas.

São elementos do consentimento informado em pesquisas:

- Informação

- Entendimento da informação

- Voluntariado em estar participando

- Competência em estar entendendo o que estará sendo desenvolvido

- Consentimento ou autorização em estar participando 
Não-maleficência - $O$ conceito de não-maleficência é o de não infringir danos e está associado com a máxima "Primum non nocere", ou seja, acima de tudo, ou primeiramente não causar danos.

Beneficência - $O$ princípio da beneficência é a obrigação de ajudar os outros nos seus interesses, pesar e balancear os possíveis bens contra os possíveis danos da ação. É produzir benefícios, prevenindo danos sem criar riscos desnecessários.

Justiça - O princípio da justiça tem como objetivo, levantar as alternativas, especialmente as que envolvem riscos ou custos e benefício, e de como será a distribuição destes benefícios.

Estes, são os quatros princípios, resumidamente apresentados, e que à partir do Relatório de Belmont, passam a serem utilizados em vários documentos que abordam as questões da ética em pesquisa em todo o mundo. Segundo o modelo de análise ética principialista desenvolvida por BEAUCHAMP e CHILDRES (1989) os princípios da autonomia, nãomaleficência, beneficência e justiça são "prima facie", ou seja, a sua ordem de aplicação e importância pode variar caso a caso, não existindo um grau de importância entre eles.

\subsubsection{Normas Éticas Internacionais para as Investigações Biomédicas com Sujeitos Humanos - CIOMS/OMS}

Mas, discussões sobre o tema continuaram a acontecer. O próximo passo ficou sobre a responsabilidade do CIOMS - Conselho para a Organização Mundial de Saúde, juntamente com a OMS - Organização Mundial de Saúde. Em 1982, estes dois importantes órgãos emitiram as "Diretrizes Internacionais Propostas para a Pesquisa Biomédica em Seres Humanos". Estas diretrizes foram utilizadas, em particular, em países em desenvolvimento, ".... para definir e aplicar normas éticas em circunstâncias 
locais, estabelecer e redefinir os mecanismos adequados para a revisão ética das investigações com sujeitos humanos, considerando sua situação socioeconômica, suas leis e regulamentações, e seus mecanismos de execução e administração". Esta mesma norma foi revista em 1992 e reeditada em 1996, mantendo seu objetivo anterior acima descrito, bem como redefiniu-se políticas de ação, estabelecendo novos propósitos éticos surgidos devido ao grande avanço biológico e tecnológico ocorrido nas últimas décadas. (CIOMS 1992, p. vii; CIOMS 1996, p. vii),

Este documento trouxe, além das diretrizes da autonomia, beneficência e justiça, questões importantes como a proteção do caráter confidencial dos dados pelo o pesquisador no decorrer da pesquisa; indenização de sujeitos de investigação por lesões acidentais, os sujeitos de pesquisa que em decorrência da pesquisa sofram lesões como conseqüência de sua participação tem direito a receber assistência financeira e o direito de indenização é irrenunciável; procedimentos de avaliação, como devem ser constituídas e devem funcionar as comissões de ética em pesquisa; pesquisas com patrocinadores externos, obrigação do país financiador e do país anfitrião, em que o país patrocinador deverá submeter o protocolo de pesquisa para aprovação das autoridades pertinentes do país anfitrião, comitês de ética em pesquisa ou órgão equivalente. (CIOMS 1996)

Para complementar cabe citar FORTES (1998):

"O texto conta com quinze diretrizes e atenta para as peculiaridades das diferentes realidades existentes nos países em desenvolvimento. Ressalta a proteção de grupos vulneráveis - pessoas com transtornos mentais, crianças, prisioneiros, comunidades subdesenvolvidas, gestantes e nutrizes -- o consentimento em estudos epidemiológicos e multicêntricos e as pesquisas financiadas de fontes externas ao país onde é realizada. Vem reforçar o princípio da participação autônoma, da privacidade, da confidencialidade e 
sigilo dos dados e a necessidade dos comitês de ética em pesquisa." ( p. 107).

Apesar do grande avanço que estes guias internacionais proporcionaram para a discussão da ética em pesquisa tentando com isso, abranger vários contextos nas várias diversidades encontradas, cabe ressaltar:

"É difícil que a mera formulação de normas éticas para as investigações biomédicas com sujeitos humanos resolva todas as dúvidas morais que surjam em conseqüência destas investigações. Não obstante, as normas podem atrair a atenção dos pesquisadores, patrocinadores e integrantes de comissões de avaliação ética sobre a necessidade de considerar cuidadosamente as conseqüências éticas dos protocolos de investigação e da realização de investigações, promovendo assim, uma investigação de alto nível científico e ético. (CIOMS 1996, p.ix).

Todos estes códigos, diretrizes e normas éticas são de fundamental importância, e seus avanços teóricos conceituais têm trazido contribuições inestimáveis para á ética em pesquisa, sendo instrumentais que visam a garantia do respeito da autonomia dos sujeitos pesquisados.

\subsubsection{Guia Internacional para Análise Ética de Estudos Epidemiológicos - CIOMS/OMS}

Mas, ainda assim, havia uma preocupação por parte do CIOMS e da OMS com relação aos estudos epidemiológicos desenvolvidos principalmente em grandes populações. Desta preocupação surgiram discussões originando o " Guia Internacional para Análise Ética de Estudos Epidemiológicos", CIOMS - Genebra, 1991. 
Este Guia Internacional para Análise Ética de Estudos Epidemiológicos emerge devido aos estudos epidemiológicos desenvolvidos com o advento da AIDS. O aumento de pesquisas com vacinas e novos medicamentos nesta área e o uso de grande número de sujeitos de pesquisa em várias partes do mundo foi uma das grandes preocupações de CIOMS/OMS e pesquisadores de todo o mundo.

O Guia tem como diretrizes básicas aplicadas à área da epidemiologia: o consentimento informado de indivíduos e comunidades, ou seja, pesquisas em comunidades devem ter a aprovação do líder da comunidade, mas não invalidando a autonomia do indivíduo; maximização de benefícios: máximo benefício para os sujeitos e/ou comunidade estudada; comunicação dos resultados: os resultados devem ser retornados aos sujeitos da pesquisa através de programas informativos e devem abranger o maior número de participantes; cuidados de saúde para a comunidade que estiver sendo estudada, estes cuidados devem estar previstos na pesquisa, através da disponibilização de atendimento em serviços de saúde local; treinamento de pessoas da comunidade para assistirem a comunidade após o término da pesquisa; publicidade danosa: deve-se ter um cuidado especial para não se estigmatizar e não criar preconceitos através de publicidade ou publicações científicas relativa à comunidade estudada; respeito à moral; sensibilidade com relação as culturas diferentes: deve-se ao máximo respeitar os hábitos e costumes destas comunidades, não intervindo na sua cultura, mas não invalidando ações que possam trazer benefícios. (CIOMS 1991)

A maioria das ações desencadeadas pelo Guia de Análise de Estudos Epidemiológicos - CIOMS/OMS, buscam respeitar os sujeitos de pesquisa e propiciar retorno dos resultados às comunidades e indivíduos estudados.

"A competência e métodos de pesquisa epidemiológica com seu contínuo potencial para coleta, armazenamento e uso de dados de indivíduos e comunidades, e com alguma tensão inevitável entre os 
direitos e liberdade dos indivíduos e as necessidades da sociedade, tem assumido preocupações sociais relativas a riscos e abusos e reivindicado considerações às questões éticas envolvidas." (CIOMS 1991, p.vii).

Estas normas, diretrizes, guias éticos que regem a prática dos pesquisadores, são considerados os mais importantes e foram base para a elaboração de normalizações na área em todo o mundo. A preocupação com tema não se restringe aos documentos expostos, outros países tiveram igual interesse e desenvolveram suas próprias normas éticas em pesquisa.

\subsubsection{Resoluções sobre Ética em Pesquisa em alguns Países Mundo}

KELLY et col (1993) colaboraram com um levantamento de vários documentos sobre ética em pesquisa em todo o mundo, que exporemos à seguir:

Países como a Algéria, Colômbia, México, Arábia Saudita, Tunísia, Hong Kong, Nova Zelândia, criaram leis que normalizam ações relativas à ética em pesquisa, prevendo sanções legais em caso de não cumprimento. Para o Burundi, Malawi, Guatemala, a grande preocupação foi criar normalizações e adequações éticas para pesquisas relacionadas ao HIVIAIDS . A Declaração de Helsinque foi incorporada por alguns países como Uganda, Chile e Costa Rica, como referencial na sua prática ética em pesquisas com seres humanos. As ações nesta área no Sri Lanka são baseadas nas "Normas Éticas Internacionais para as Investigações Biomédicas com Sujeitos Humanos" do CIOMS/OMS. Em países como a Bolívia, Equador, El Salvador, Panamá, as ações nesta área estão descritas nos Códigos de Ética Médica.

No levantamento sobre normalizações em ética em pesquisa com seres humanos, podemos perceber que a grande preocupação é com 
relação às pesquisas biomédicas e/ou médicas. Mas uma normalização, em especial, chama nossa atenção. As Filipinas editou uma Ordem Administrativa sobre Políticas de Pesquisa e Guias do Ministério da Saúde (Guia para Pesquisas Envolvendo Seres Humanos) havendo a preocupação especial com pesquisas desenvolvidas em comunidades, cabendo citar:

“... consentimento informado não é necessário quando a comunidade base de pesquisa compromete-se a desenvolver pesquisas tais como: tratamento experimental de suprimento de águas, ou testes de novos inseticidas, agentes profiláticos ou imunológicos; nutricionais ou substitutos, etc., embora sejam essenciais para a comunidade e em particular para seu líder o mesmo deverá ser amplamente informado sobre o estudo. Sujeitos com opiniões divergentes, podem optar por não participar. A decisão da participação da comunidade se apoia na autoridade responsável pela saúde da comunidade." (CIOMS 1993)

Todo este movimento, com relação a ética em pesquisa no mundo, gerou uma grande reflexão por parte de médicos e cientistas brasileiros, e neste movimento, foram elaborados alguns documentos sobre o tema, conforme demonstraremos à seguir. 


\section{6. Ética em Pesquisa no Brasil}

No Brasil, a discussão da ética em pesquisa vem sendo ampliada nas últimas décadas. Em 1985, foram traduzidas as "Diretrizes e Normas Internacionais Propostas para a Pesquisa Biomédica em Seres Humanos", elaborada pelo CIOMS/OMS, em sua primeira versão de 1981.

Em 1988, através da ação de médicos e pesquisadores em todo o País, o Brasil deu o primeiro passo no sentido de estabelecer uma regulamentação legal, quando o Conselho Nacional de Saúde (CNS) elaborando a Resolução 01/88, que aprova normas de pesquisas para a área de saúde.

\subsubsection{Resolucão 01/88}

A Resolução 01/1988 - possui um vasto conteúdo sobre a ética em pesquisa, sendo que, grande parte deste conteúdo está relacionado à ética em pesquisa na área biomédica.

A Resolução 01/1998 - Conselho Nacional de Saúde - (CNS) dispõe em seus capítulos:

Capítulo I - o objetivo principal é normalizar pesquisas na área de saúde.

Capítulo II - Trata dos aspectos éticos da pesquisa em seres humanos, onde enfatiza o consentimento informado do participante da pesquisa e/ou representante legal; riscos e benefícios - devendo prevalecer os benefícios sobre os riscos previsíveis; garantindo o bem-estar do participante, respeito à dignidade, privacidade e proteção ao participante da pesquisa contra qualquer risco possível, bem como, todo projeto de 
pesquisa deverá ter o parecer favorável do Comitê de Ética e de Segurança Biológica, quando for o caso.

Capítulo III - Disserta sobre a pesquisa de novos recursos profiláticos, terapêuticos e de reabilitação, bem como a necessidade de pesquisas serem aprovadas por um Comitê de Ética da Instituição na qual será desenvolvida a pesquisa; e faz considerações sobre como deverá ser composto o protocolo de pesquisa.

Capítulo IV - Trata de pesquisa com menores de idade (idade inferior à 18 anos completos) e em indivíduos sem condições de dar conscientemente seu consentimento em participar.

Capítulo V - Trata da pesquisa em mulheres em idade fértil; mulheres grávidas, pesquisa em conceptos, pesquisas durante o trabalho de parto, no puerpério e na lactação, pesquisa em óbito fetal.

Capítulo VI - Trata de pesquisas em indivíduos com presumível restrição a espontaneidade do consentimento. Deste grupo fazem parte os empregados de hospitais e laboratórios militares, reclusos ou internos em centros de readaptação social e todos os indivíduos cujo consentimento de participação possa ser influenciado por alguma autoridade.

Capítulo VII - Trata de Pesquisas em órgãos, tecidos e seus derivados, cadáveres e partes de seres humanos.

Capítulo VIII - Trata da pesquisa farmacológica (estudos de medicamentos e produtos biológicos para uso em seres humanos).

Capítulo IX - Trata da pesquisa de outros recursos novos - este capítulo abrange o estudo de materiais, enxertos, transplantes, próteses, procedimentos físicos, químicos e cirúrgicos, instrumentos, aparelhos, 
órgãos artificiais e outros métodos de prevençãoldiagnóstico, tratamento e reabilitação realizados em seres humanos.

Capítulo X - Trata da pesquisa com microorganismos patogênicos ou material biológico que possa contê-los;

Capítulo XI - Trata das pesquisas que impliquem na construção e manejo de ácidos nucléicos - recombinantes.

Capítulo XII - Trata da pesquisa com isótopos radioativos, dispositivos e geradores de radiações ionizantes e eletromagnéticas.

Capítulo XIII - Trata dos Comitês internos nas instituições de saúde.

Capítulo XIV - Trata da execução da pesquisa nas instituições de saúde.

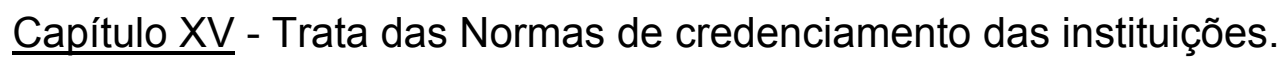

A Resolução 01/88, estabelece normas em pesquisa enfatizando as pesquisas na área biomédica e farmacológica, não havendo uma grande abrangência com relação as áreas psicossociais, ou o envolvimento de grupos e/ou comunidades.

Conforme cita FORTES (1998). Apesar dos avanços conceituais que trouxe, sua repercussão foi limitada, ensejando sua reformulação, que resultou na atual Resolução 196/96 - Conselho Nacional de Saúde CNS/MS. 


\subsubsection{Resolução 196/96}

A atual Resolução 196, de 10 de outubro de 1996, grande marco da ética em pesquisa no Brasil, baseia-se em vários documentos nacionais e internacionais, como o Código de Nuremberg, Declaração de Helsinque, Guias para pesquisas biomédicas e epidemiológicas do CIOMS/OMS, bem como, diversos documentos nacionais, Código do Direito do Consumidor, Estatuto da Criança e do Adolescente, Código Civil e Penal, Lei Orgância da Saúde 8.080, dentre outros documentos de igual importância. Sua elaboração teve a colaboração de profissionais de diversas áreas de atuação com relação direta com a prática de pesquisa, sendo considerada um dos mais completos documentos sobre o assunto.

Com relação a atual Resolução 196/1996, cabe ressaltar:

"A versão preliminar da nova Resolução foi apresentada e discutida no I Congresso Brasileiro de Bioética, realizado na cidade de São Paulo em julho de 1996. A 9 de outubro de 1996, o CNS aprovou a nova Resolução, que foi publicada no Diário Oficial da União no dia 16 de outubro de 1996 como Resolução 196/96. No preâmbulo dessa Resolução estão citadas as normas e a legislações brasileiras pertinentes. Isso foi possível porque o CNS contou com a colaboração do Ministério Público e da OAB." (HOSSNE e VIEIRA 1998, p.99).

A Resolução 196/96 - Conselho Nacional de Saúde - CNS/MS, incorpora em seus artigos:

I - Preâmbulo - onde são feitas considerações sobre a fundamentação da Resolução. A Resolução incorpora, sob a ótica do indivíduo e das coletividades, os quatro referenciais básicos da bioética: autonomia, nãomaleficência, beneficência e justiça, entre outros, e visa assegurar os direitos e deveres que dizem respeito à comunidade científica, aos sujeitos 
da pesquisa e ao Estado, ressalta, ainda, a possibilidade de se revisar periodicamente a Resolução, conforme as necessidades que surgirem nas áreas tecnocientíficas e ética.

II - Termos e Definições: Neste artigo, conceitua-se o que é: pesquisa; pesquisa envolvendo seres humanos; protocolo de pesquisa; pesquisador responsável; instituição de pesquisa; promotor; patrocinador; risco da pesquisa; dano associado ou decorrente da pesquisa; sujeito da pesquisa; consentimento livre e esclarecido; indenização; ressarcimento; comitês de ética em pesquisa; vulnerabilidade e incapacidade.

III - Aspectos éticos da pesquisa envolvendo seres humanos, implica a eticidade, onde é feita uma descrição dos quatro referenciais básicos da bioética: autonomia - consentimento livre e esclarecido de indivíduos e grupos vulneráveis e incapazes, respeitando sempre sua dignidade e autonomia; riscos e benefícios - máximo de benefícios e o mínimo de danos e riscos; não maleficência - evitar danos previsíveis; justiça e eqüidade relevância social da pesquisa visando o retorno aos sujeito da pesquisa estudado.

VI - Consentimento Livre e Esclarecido - trata do respeito à dignidade do sujeito pesquisado. Toda pesquisa somente poderá se processar após 0 consentimento livre e esclarecido dos sujeitos, indivíduos ou grupos que por si só e/ou por seus representantes legais manifestem o seu consentimento em participar da pesquisa. É necessário, que o documento seja elaborado em linguagem acessível, devendo ser elaborado pelo pesquisador responsável e aprovado pelo comitê de ética.

V - Riscos e Benefícios - A Resolução 196/1996, considera que toda pesquisa envolvendo seres humanos envolve riscos. $O$ dano poderá ser imediato ou tardio, comprometendo o indivíduo ou a coletividade. Deve-se prever, basicamente, que o risco seja mínimo e sempre deverá ser 
justificado pelo pesquisador responsável, devendo ser explicitado no protocolo de pesquisa à ser enviado ao Comitê de Ética em Pesquisa.

VI - Protocolo de Pesquisa - O protocolo de pesquisa deverá ser submetido ao Comitê de Ética, contendo sempre a identificação do projeto, do pesquisador responsável e instituição e/ou patrocinador. A descrição da pesquisa deverá seguir os itens previstos no artigo VI-2 constante da Resolução 196/1996, dentre estes dados é relevante considerar: justificativa da importância da pesquisa; explicitação das responsabilidades do pesquisador; declaração de que os resultados serão tornados públicos, sendo eles favoráveis ou não; informações relativas ao sujeito da pesquisa, na qual conste o porque da escolha de determinado sujeito da pesquisa descrevendo as medidas de proteção ou minimização de qualquer risco eventual; "Curriculum Vitae" dos pesquisadores e demais colaboradores e por fim, termo de compromisso do pesquisador responsável e da instituição, que se comprometa a cumprir o que foi considerado no protocolo de pesquisa.

VII - Comitê de Ética em Pesquisa - CEP - A Resolução 196/1996, prevê que: toda e qualquer pesquisa envolvendo seres humanos deverá ser submetida à apreciação de um Comitê de Ética em Pesquisa ("CEP"). $O$ CEP deverá ser constituído em locais onde se desenvolvam pesquisas. São colegiados multi e transdiciplinares, compostos de no mínimo 7 membros, não devendo haver mais de 50\% dos seus membros pertencente à mesma categoria profissional. No caso da impossibilidade de constituir um CEP, a instituição deverá enviar os protocolos de pesquisa para análise do Comitê Nacional de Ética em Pesquisa - CONEP.

As atribuições básicas do CEP são: (i) revisar todos os protocolos de pesquisa envolvendo seres humanos; (ii) emitir parecer por escrito no prazo de 30 dias; (iii) garantir a confidencialidade de todos os dados referentes ao protocolo de pesquisa analisado; (iv) acompanhar o desenvolvimento dos 
projetos; (v) desenvolver papel consultivo e deliberativo e promover discussões e reflexões sobre ética na ciência; (vi) receber dos sujeitos da pesquisa e de qualquer outra parte denúncias de abusos ou notificações referente a fatos relativos aos curso da pesquisa, tendo autonomia de decidir sobre a continuação ou suspensão da mesma; (vii) requer sindicância à direção da instituição responsável pela pesquisa em caso de comprovação de denúncia de irregularidades e comunicar o ocorrido ao Comitê Nacional de Ética em Pesquisa - CONEP.

VIII - Comitê de Ética em Pesquisa - ("CONEP") - O CONEP é uma instância colegiada, de natureza consultiva, deliberativa, normativa, educativa, independente e vinculada ao Conselho Nacional de Saúde - CNS. O CONEP, possui as mesmas atribuições dos Comitês de Ética em Pesquisa, mas de forma mais abrangente, tendo como principais atribuições : (i) o exame dos aspectos éticos em pesquisa envolvendo seres humanos, a atualização e adequação das normas atinentes, consultando sempre a sociedade quando julgar necessário.

O CONEP deverá submeter ao Conselho Nacional de Saúde para deliberação: (i) propostas de normas gerais a serem aplicadas em pesquisas envolvendo seres humanos, inclusive a modificação da Resolução 196/1996; (ii) plano de trabalho anual; (iii) relatório anual das atividades, inclusive resumo dos CEPs estabelecidos e dos projetos analisados.

XI - Operacionalização - Este artigo dispõe: Todo e qualquer projeto de pesquisa envolvendo seres humanos deverá obedecer às recomendações desta Resolução e dos documentos endossados em seu preâmbulo. A Responsabilidade do pesquisador é indelegável, indeclinável e compreende os aspectos éticos e legais.

Através deste breve resumo da Resolução 196/1996 é possível verificar sua amplitude e diversidade. Em 1998, dois anos após a instituição 
da Resolução 196/96, o CONEP concedeu a criação de 160 Comitês de Ética em Pesquisa locais em várias universidades públicas e privadas e diversas instituições de saúde em todo o Território Nacional (EDITORIAL, CADERNOS DE ÉTICA EM PESQUISA 1998). Baseado neste resultado consideramos que a importância da questão não será somente conceitual mas também prática, e de forma consciente por parte dos profissionais da área e todos os envolvidos afins.

Apesar de todas as atribuições de Comitês de Ética, no Brasil e em outros países, os mesmos funcionam, também como um "mecanismo de controle". A criação de Comitês de Ética em Pesquisa tem feito com que agências de fomento e revistas indexadas exigissem que todos os projetos e/ou artigos para publicação fossem aprovados por um Comitê de Ética em Pesquisa.

A Resolução 196/96 vem promovendo uma ampla reflexão sobre o comportamento dos pesquisadores, garantindo a manutenção do princípio ético da justiça e respeito a dignidade do sujeito pesquisado na sua relação com o pesquisador.

\subsubsection{Resolução $251 / 97$}

Apesar de toda a complexidade da Resolução 196/96, verificou-se a necessidade de ser estar criando uma resolução específica para pesquisas como novos fármacos, medicamentos, vacinas e testes diagnósticos. Em 05 de agosto de 1997, é aprovada em Plenário do Conselho Nacional de Saúde as "Normas de Pesquisa com Novos Fármacos, Medicamentos, Vacinas e Testes Diagnósticos Envolvendo Seres Humanos." (RESOLUÇÃO CNS 251/97)

A Resolução 251/97, deverá também, reportar-se à Resolução do GMC (Grupo Mercado Comum), do qual o Brasil é associado e que dispõe 
de regulamento técnico sobre a verificação de boas práticas de pesquisa clínica.

Deverão obedecer estas normas, todos os projetos de pesquisa de farmacologia clínica (fases I, II, III e IV) de produtos não registrados no Brasil. Deve-se sempre respeitar a dignidade e bem-estar do sujeito envolvido na pesquisa. Toda pesquisa nesta área deve estar justificada em normas e conhecimentos científicos consagrados pela literatura pertinente, bem como, a investigação de novos produtos devem acarretar avanços significativos com relação aos já existentes.

A Resolução 251/97, incorpora todas as disposições contidas na resolução 196/96, acrescentando algumas disposições relevantes no seu I Preâmbulo, com relação à pesquisas nesta área de atuação:

(i) toda pesquisa nesta área deverá ser reportada ao Grupo Mercado Comum (GMC) do qual o Brasil é signatário, e que dispõe de regulamento técnico sobre a verificação de boas práticas de pesquisa clínica;

(ii) caso haja algum conflito de interesse envolvido na pesquisa, deve-se prevalecer a dignidade e o bem estar do sujeito da pesquisa sobre os interesses sejam eles econômicos, da ciência ou da comunidade;

(iii) pesquisas nesta área devem estar alicerçadas em normas e conhecimentos científicos consagrados e em experimentos conhecidos pela literatura pertinente; e

(iv) é necessário que a investigação de novos produtos seja justificada e que os mesmos acarretem avanços aos já existentes. 
(v) todas as pesquisas nesta área devem percorrer as Fases I, II, III e IV. A fase I é desenvolvida com pessoas voluntárias, em geral sadias, a Fase II é desenvolvida em pacientes afetados por uma determinada enfermidade ou condição patológica, Fase III, é o estudo terapêutico ampliado, para se verificar o resultado do risco/benefício a curto e longo prazos das formulações do princípio ativo e de maneira global (geral o valor terapêutico relativo; Fase IV, são as pesquisas realizadas após a comercialização do produto e/ou especialidade medicinal;

As demais atribuições da resolução 251/97 incorporam capítulos da Resolução 196/96, anteriormente descrita, tais como: Responsabilidade do Pesquisador; Protocolo de Pesquisa; Atribuições do CEP; e Operacionalização.

Através da introdução, verificamos que vários são os códigos, diretrizes e normas éticas, nacionais e internacionais sobre ética em pesquisa envolvendo seres humanos. Grande parte desta documentação está relacionada à questão da ética em pesquisa direcionada à área biomédica.

Apesar dos esforços e contribuições inegáveis que estes códigos, diretrizes e normas vêm proporcionando para a ética em pesquisa no Brasil, e no mundo e, particularmente considerando a contribuição do Guia Internacional de Revisão Ética em Pesquisa Epidemiologia editado pelo Conselho Internacional da Organização Mundial de Saúde - OMS, em 1991, cujo conteúdo vem ao encontro com problemas enfrentados por países em desenvolvimento, julga-se relevante estarmos estudando a ética em pesquisa na área de saúde pública, tendo como referencial nossa própria realidade. 
A saúde pública é uma área de grande abrangência e diversidade, seu caráter multidisciplinar acentua sua importância, sendo a mesma diretamente voltada para prática de políticas públicas, e de fundamental importância em nosso contexto sócioeconômico .

Outro fator que chama atenção para este estudo, é a pouca literatura relacionada ao tema, o que faz crer na importância de estudos abordando a ética em pesquisa direcionada à pesquisa em saúde pública.

A proposta de estudo foi analisar revistas nacionais de grande circulação na área de saúde pública, onde objetivamos artigos publicados em compreender quais as diretrizes éticas que subsidiaram as ações dos pesquisadores nesta área antes da implantação da Resolução 196/96 do Conselho Nacional de Saúde. 
2. Objetivo 


\section{Objetivo Geral}

- Análise ética em artigos científicos da área de saúde pública, publicados entre 1990 a 1996, tendo como base as Diretrizes e Normas Regulamentadoras de Pesquisa Envolvendo Seres Humanos - Resolução 196/1996 - Conselho Nacional de Saúde. (“Resolução 196/96”). 
3. Metodologia 
A metodologia empregada ficou dividida em dois momentos. No primeiro momento efetuou-se uma caracterização dos artigos publicados na Revista de Saúde Pública e Cadernos de Saúde Pública publicado entre 1990 e 1996. Para o trato destes dados utilizamos o software estatístico SPSS versão 8.0, da Faculdade de Saúde Pública - USP.

No segundo momento, efetuou-se a análise qualitativa a partir de trechos retirados das Revistas de Saúde Pública e Cadernos de Saúde Pública.

\subsection{Tipo de Pesquisa}

A pesquisa teve caráter analítico-descritivo. Com base na Resolução 196/96, foram levantadas categorias de análise que serviram para subsidiar a análise dos artigos científicos.

A análise ética dos artigos científicos orientou-se pela utilização do modelo de análise ética principialista, que incorpora os quatro referenciais básicos da bioética: autonomia, beneficência, não-maleficência e justiça, constante na Resolução 196/96.

Baseado nestes quatro princípios, enfatizamos como categorias de análise: (i) consentimento livre e esclarecido; (ii) proteção aos grupos vulneráveis e aos legalmente incapazes; (iii) confidencialidade; (iv) privacidade; (v) proteção da imagem; (vi) estigmatização de indivíduos, grupos e comunidade; (vii) benefícios da pesquisa para indivíduos, grupos e comunidades pesquisadas, bem como, o retorno social da pesquisa. 
Neste tipo de pesquisa bibliográfica nosso diálogo é com o artigo científico analisado, procurando estabelecer identificações com as categorias éticas previamente estabelecidas.

\subsection{Pré Teste}

Coletamos dados de 20 (vinte) questionários com propósito de validar o instrumento de coleta de dados utilizado para o da pesquisa. A partir dos resultados encontrados, elaboramos os critérios de seleção e organização do instrumental de coleta de dados. Citaremos no decorrer deste capítulo as contribuições decorrentes do pré teste.

\subsection{Critérios de Seleção}

Analisamos artigos científicos que envolviam direta ou indiretamente seres humanos, da Revista de Saúde Pública e Cadernos de Saúde Pública, publicados no período de 1990 a 1996.

Estas duas revistas possuem a finalidade de publicar artigos originais e inéditos e que contribuam para o conhecimento e desenvolvimento da saúde pública e ciências afins, disseminando boa parte dos trabalhos desenvolvidos nesta área de estudo.

Foram selecionados somente os artigos cujas pesquisas envolviam direta ou indiretamente seres humanos, e que foram desenvolvidos no Brasil, publicados por autores brasileiros e/ou com parceria com autores estrangeiros, desde que a pesquisa tenha sido desenvolvida no Brasil, excluindo todos os artigos cuja pesquisa tenha sido desenvolvida no exterior. 


\section{4. $\quad$ Coleta de Dados}

Os artigos científicos da Revista de Saúde Pública e Cadernos de Saúde Pública foram analisados no período compreendido de 1990 a 1996. Cada artigo foi detalhadamente lido e as informações referentes à caracterização das revistas e com relação às categorias éticas previamente estabelecidas foram copiadas de forma literal.

Enfocaremos as categorias éticas utilizadas no próximo item de "Instrumental para a Coleta dos Dados".

\subsection{Instrumental para a Coleta dos Dados}

A coleta de dados foi efetuada através de instrumento para coleta de dados, através do qual foram levantadas as variáveis que comportam a análise. (Anexo 1)

\section{- Primeiro Momento}

Nossa primeira etapa foi o levantamento das seguintes variáveis de identificação:

- nome da revista, nome do artigo, período de publicação, ano e paginação;

- A pesquisa envolve seres humanos:

- Sim

- Não

- Em caso afirmativo de que forma:

- $\quad$ participação direta individual 
participação direta coletivamente (grupos e/ou coletividades)

participação indireta (manejo de informações, dados secundários, manejo de material biológico)

Participação direta e indireta (coleta de dados e abordagem direta ao sujeito da pesquisa)

outras: especificar

- Qual o tipo de instituição onde se insere o sujeito da pesquisa:

- $\quad$ Saúde

- $\quad$ Educação

- $\quad$ Assistência Social

- Lazer

- $\quad$ Instituições de Reabilitação

- $\quad$ Associações religiosas

- $\quad$ Empresas, indústrias, escritórios

- Comunidades diversas

- $\quad$ Outras - Especificar

Com base no pré-teste encontramos as seguintes associações com relação às instituições onde se inserem os sujeitos de pesquisa:

- Saúde: hospitais - pacientes internados e não internados pronto socorros, postos de saúde, centros de saúde

- Educação: Ensino fundamental, ensino médio e ensino superior

- Assistência Social: creches, asilos, orfanatos, centros comunitários

- Lazer: clubes, centros esportivos, shoppings, bares, livrarias

- Instituições de Reabilitação: presídio, Febem, SOS-Criança

- Comunidades diversas incluindo indígenas

- Tipo de Pesquisa:

- Biológica

- Psicológica

- Social

- $\quad$ Epidemiológica

- $\quad$ Fármacos, medicamentos, vacinas e testes diagnósticos novos (fases I, II e II)

- Ambiental 
Nutricional

- Educacional

- Econômica

- Clínica e/ou cirúrgica

- $\quad$ Genética humana

- $\quad$ Reprodução humana

- $\quad$ Avaliação de programas/serviços/assessorias

- $\quad$ Outras: especificar

Sendo a área de saúde pública abrangente na sua atuação, levantamos as possíveis pesquisas elaboradas, considerando a citação feita pelo(s) autor(es) com relação a tipologia da mesma e no caso de não haver citação direta do tipo de pesquisa, escolhemos a tipologia que mais se identificava com a pesquisa.

- Agência de fomento:

- Nacional

- Estrangeira

- Nacional e estrangeira

- Não consta agência financiadora

- Segundo Momento

No segundo momento levantamos e copiamos integralmente trechos, que denominamos "citações" ou "relato do autores", que possuíam relação direta com as categorias previamente estabelecidas, retiradas da Resolução 196/96, conforme mostramos à seguir:

- O respeito devido à dignidade humana exige que toda pesquisa se processe após consentimento livre e esclarecido dos sujeitos, indivíduos ou grupos que por si e/ou por seus representantes legais manifestem a sua anuência à participação na pesquisa. 
- a liberdade do consentimento deverá ser particularmente garantida para aqueles sujeitos que, embora adultos e capazes, estejam, expostos a condicionamentos específicos ou à influência de autoridade, especialmente estudantes, militares, empregados, presidiários, internos, centros de readaptação, casas-abrigo, asilos, associações religiosas e semelhantes, assegurando-lhes a inteira liberdade de participar ou não da pesquisa sem quaisquer represálias.

- Em comunidades culturalmente diferenciadas, inclusive indígenas, deve-se contar com a anuência antecipada da comunidade através dos seus próprios líderes, não se dispensando, porém, esforços no sentido do consentimento individual.

- Garantir que as pesquisas em comunidades, sempre que possível, traduzir-se-ão em benefícios cujos efeitos continuem a se fazer sentir após a sua conclusão. O projeto deve analisar as necessidades de cada um dos membros da comunidade e analisar as diferenças presentes entre eles, explicitando como será assegurado o respeito às mesmas.

- Prever procedimentos que assegurem a confidencialidade e a privacidade, a proteção da imagem e a não estigmatização, garantindo a não utilização das informações em prejuízo das pessoas e/ou comunidades, inclusive em termos de auto-estima, de prestígio e/ou econômico-financeiro. 
Consideramos para a coleta de dados referentes às categorias éticas previamente estabelecidas:

- Não se aplica - quando a categoria de análise não tiver nenhuma identificação com o artigo analisado;

- Nada Consta - quando o artigo não fizer nenhuma referência com a categoria de análise; e

- No caso de haver identificação do artigo analisado com relação a categoria de análise, a parte identificada no artigo será transcrita no todo ou em parte.

\subsection{Análise dos Dados}

As resposta referentes à caracterização dos artigos no item "primeiro momento foram analisados segundo a freqüência das respostas levantadas. Os dados relativos ao "segundo momento" optamos por utilizar a análise de conteúdo. A interpretação do material coletado foi baseada na teoria de TRIVIÑOS (1987).

A pesquisa qualitativa poderá ser desenvolvida através de retratos (ou descrições), em narrativas, ilustradas com declarações das pessoas para dar fundamento concreto necessário, com fotografias, fragmentos de entrevistas e acompanhamento de documentos pessoais (TRIVIÑOS 1987).

TRIVIÑOS (1987) afirma que a pesquisa qualitativa de tipo históricoestrutural, dialética, parte também da descrição que intenta captar não só a aparência do fenômeno, como também sua essência. Busca, porém, as causas da existência dele, procurando explicar sua origem, suas relações, suas mudanças e se esforça por intuir as conseqüências que terão para a vida humana. (p.129) 


\subsection{Considerações Éticas}

Os dados trabalhados foram secundários. Seguimos as regras adotadas pela Faculdade de Saúde Pública, através de seu "Guia de apresentação de Teses", onde identificamos os artigos analisados e discutidos, não havendo em nenhum momento, a identificação dos autores no conteúdo da análise e discussão, para tanto, numeramos todos os formulários. 
4. Resultados e Discussão 


\subsection{Caracterização da Amostra}

Identificamos o total de 568 artigos científicos, sendo que 384 (67,6\%) foram da Revista de Saúde Pública e $184(32,4 \%)$ do Cadernos de Saúde Pública.

Na Tabela 1, verificamos a produção científica publicada na Revista de Saúde Pública e Cadernos de Saúde Pública, no período de 1990 a 1996. Percebemos que houve um aumento gradativo a cada ano, havendo uma pequena queda nos anos de 1991 e 1994.

Tabela 1 - Distribuição da produção científica publica na Revista de Saúde Pública e Cadernos de Saúde Pública, no período de 1990 a 1996, segundo ano de publicação

\begin{tabular}{ccc}
\hline Ano & Freqüência & $\%$ \\
\hline 1990 & 78 & $13,7 \%$ \\
1991 & 63 & 11,1 \\
1992 & 70 & 12,3 \\
1993 & 87 & 15,3 \\
1994 & 76 & 13,4 \\
1995 & 90 & 15,8 \\
1996 & 104 & 18,3 \\
\hline Total: & 568 & 100 \\
\hline
\end{tabular}

Do total de 568 artigos levantados, constatamos que apenas 296 $(52,1 \%)$ envolvem seres humanos e $96(17,1 \%)$ são de autores estrangeiros, como é possível verificar abaixo na tabela 2 e 3 , o que nos leva a um universo de 296 artigos analisados. 
Tabela 2 - Distribuição da produção científica publicada na revista de Saúde Pública e Cadernos de Saúde Pública publicado no período de 1990 a 1996, segundo envolvimento de seres humanos.

\begin{tabular}{lcc}
\hline \multicolumn{1}{c}{ Forma de Abordagem } & Freqüência & $\%$ \\
\hline $\begin{array}{l}\text { Envolvem seres humanos de } \\
\text { forma direta ou indireta }\end{array}$ & 296 & 52,1 \\
$\begin{array}{l}\text { Não envolvem seres } \\
\text { humanos }\end{array}$ & 176 & 31,0 \\
\hline Total: & 472 & $83,1 \%$ \\
\hline
\end{tabular}

À partir deste momento estaremos considerando somente os artigos que envolvem seres humanos de forma direta ou indireta $(\mathrm{N}=296)$, que foram utilizados para análise do nosso trabalho.

$\mathrm{Na}$ Tabela 3, podemos verificar qual a forma de envolvimento dos sujeitos de pesquisas, conforme artigos analisados.

Tabela 3 - Distribuição dos artigos referentes a pesquisas que envolvam seres humanos publicados na Revista de Saúde Pública e Cadernos de Saúde Pública no período de 1990 - 1996, segundo forma e envolvimento dos sujeitos.

\begin{tabular}{lcc}
\hline \multicolumn{1}{c}{ Tipo de Participação } & Freqüência & $\%$ \\
\hline Participação direta individual & 182 & 61,5 \\
Participação direta coletiva & 10 & 3,4 \\
Participação indireta & 78 & 26,4 \\
\hline Participação direta e indireta & 26 & 8,8 \\
\hline Total: & 296 & 100 \\
\hline
\end{tabular}

Na Tabela 4, pontuamos principais instituições e/ou locais utilizados para a realização de pesquisas na área de saúde pública, conforme 
demonstraram os artigos analisados que envolveram seres humanos, conforme verificamos abaixo:

Tabela 4 - Distribuição dos artigos referentes a pesquisas que envolviam seres humanos publicados na Revista de Saúde Pública e Cadernos de Saúde Pública no período de 1990 - 1996, segundo instituição e/ou locais mais utilizados para a realização de pesquisas.

\begin{tabular}{lcc}
\hline \multicolumn{1}{c}{ Tipo de Instituição } & Freqüência & \% \\
\hline Saúde & 136 & 45,9 \\
Educação & 28 & 9,5 \\
Assistência Social & 2 & 0,7 \\
Lazer & 2 & 0,7 \\
Empresas, $\quad$ indústrias, & 53 & 17,9 \\
escritórios & 33 & 11,1 \\
Comunidades diversas & 42 & 14,2 \\
Domicílios & 296 & 100 \\
\hline Total: & & \\
\hline
\end{tabular}

A Tabela 5 chama a atenção pelo número de pesquisas epidemiológicas 125 (42,2\%), seguidas pelas pesquisas na área biológica 60 $(20,34 \%)$, possivelmente, por serem consideradas as áreas que mais caracterizam a saúde pública e por receberem maior parte dos investimentos destinados a pesquisas nesta área.

\footnotetext{
* Baseado no pré teste, detalhamos no capítulo "Metodologia" quais foram os tipos de instituições na área de saúde, educação, assistência social, lazer, comunidades diversas, citados nos artigos identificados.
} 
Tabela 5 - Distribuição dos artigos referentes a pesquisas que envolvem seres humanos publicados na Revista de Saúde Pública e Cadernos de Saúde Pública no período de 1990 - 1996, segundo tipologia mínima da pesquisa.

\begin{tabular}{lcc}
\hline $\begin{array}{c}\text { Tipologia Mínima da } \\
\text { Pesquisa }\end{array}$ & Freqüência & \% \\
\hline Epidemiológica & 125 & 42,2 \\
Biológica e/ou física & 60 & 20,3 \\
Nutricional & 41 & 13,9 \\
Ambiental & 21 & 7,1 \\
Social & 19 & 6,4 \\
Psicológica/psiquiátrica & 10 & 3,4 \\
Avaliação de programa, & 9 & 3,0 \\
serviços/assessorias & & \\
Educacional & 3 & 2,7 \\
Farmacológica & 296 & 1,0 \\
\hline \multicolumn{2}{c}{ Total: } &
\end{tabular}

$\mathrm{Na}$ Tabela 7, verificamos a distribuição dos financiamentos das pesquisas que envolviam seres humanos. As financiadoras mais utilizadas foram as nacionais $144(48,6 \%)$. Em $113(38,2 \%)$ não constava a financiadora da pesquisa, possivelmente, por não ser uma obrigatoriedade das normas das Revistas analisadas, na época da publicação.

Tabela 6 - Distribuição dos artigos referentes a pesquisas que envolvam seres humanos publicados na Revista de Saúde Pública e Cadernos de Saúde Pública no período de 1990 1996, segundo as financiadoras utilizadas para 0 desenvolvimento das pesquisas.

\begin{tabular}{|c|c|c|}
\hline Financiamento & Freqüência & $\%$ \\
\hline Financiamento nacional & 144 & 48,6 \\
\hline Não consta financiadora & 113 & 38,2 \\
\hline $\begin{array}{l}\text { Financiamento misto: } \\
\text { nacional e estrangeiro }\end{array}$ & 24 & 8,1 \\
\hline Financiamento estrangeiro & 15 & 5,1 \\
\hline Total: & 296 & 100 \\
\hline
\end{tabular}




\section{Autonomia e Consentimento}

Enfocaremos conjuntamente as categorias relativas à autonomia e ao consentimento retiradas da Resolução 196/96 e que guiaram nossa coleta de dados. Todas as categorias abordam principalmente os sujeitos de pesquisa adultos e autônomos e sujeitos com competência reduzida que de alguma forma necessitam do consentimento de representantes legais, conforme categoria abaixo descrita:

- O respeito devido à dignidade humana exige que toda pesquisa se processe após consentimento livre e esclarecido dos sujeitos, indivíduos ou grupos que por si e/ou por seus representantes legais manifestem a sua anuência à participação na pesquisa.

A maioria dos códigos e resoluções, nacionais e internacionais, enfatizam a autonomia como o respeito às pessoas, respeito à escolha, respeito à sua capacidade de autodeterminação, e respeito em defendê-los em sua vulnerabilidade, sempre tratando-as com dignidade. (CIOMS 1996, RESOLUÇÃO 196/96, RELATÓRIO BELMONT 1974, DECLARAÇÃO DE HELSINQUE, 1996)

Autonomia é um termo derivado do grego auto (próprio) e nomos (lei, regra, norma). Refere-se à capacidade do ser humano de decidir o que "bom", o que é seu "bem-estar", de acordo com valores, expectativas, necessidades, prioridades e crenças próprias, é o autogoverno, autodeterminação da pessoa de tomar decisões que afetem sua vida, sua saúde, sua integridade físico-psíquica, suas relações sociais. (MUÑOZ e FORTES 1998).

Complementando, para PESSINI e BARCHIFONTAINE (1997) autonomia significa a capacidade de se autogovernar, escolher, dividir, avaliar, sem restrições internas ou externas. 
Para SEGRE e COHEN (1995) autonomia é a condição de posicionarse entre a emoção e a razão, sendo que essa escolha de posição é ativa e autônoma.

Ainda, neste sentido, para SEGRE et al (1998) a autonomia não se atribui a ninguém: cada um tem a própria. As influências sobre a personalidade certamente existem, em todas as pessoas. São elas de índole genética, cultural, decorrente de "doenças", de traumas físicos ou psíquicos. Mas, dentro desta visão de cada pessoa, "de dentro para fora", e não por julgamento de terceiros, cada ser pode sentir-se soberano ao exercer algum tipo de autodeterminação. (p.23)

Verificamos, que em 68 (23\%) artigos analisados consideravam de forma direta ou indireta as escolhas feitas pelo sujeito de pesquisa. Encontramos palavras como: "recusa", "voluntários", "autorização", "explicação e "concordância".

Vejamos, o exemplo de pesquisa publicada em 1993, realizada para conhecer sobre a anemia falciforme como problema de saúde pública no Brasil: "Os pacientes foram convidados a participar dessas entrevistas, respeitando-se sempre a sua disposição para as mesmas, bem como, a sua disponibilidade de tempo." (178). Muitas vezes, respeitar a autonomia, o momento e a disponibilidade dos sujeitos de pesquisa, demonstram por parte dos pesquisadores, consideração pelas escolhas e condições internas ou externas do sujeito de pesquisa.

Outro exemplo, encontramos em estudo publicado em 1996 sobre uma experiência educacional de incentivo ao aleitamento materno e estimulação do bebê, para mães de nível sócio-econômico baixo: Estudo Preliminar. Encontramos a seguinte citação: "todas as gestantes, com (....) a 
(...) semanas de gravidez, agendadas nestes postos foram convidadas a participar da pesquisa. De um total de 40 convidadas, 31 aceitaram." (530).

O fato de não explicitarem a palavra consentimento não quer dizer obrigatoriamente que não o solicitaram. A recusa em participar de uma pesquisa, pode ser considerada um fato positivo, trazendo implícita a idéia do consentimento demonstrando que os sujeitos de pesquisa tiveram condições de estarem decidindo autonomamente.

E, em outro relato, de pesquisa publicada no ano de 1995, com o intuito de investigar sobre a hipertensão arterial na llha do Governador, percebe-se o respeito pela autonomia dos sujeitos de pesquisa conforme citação: "A todos (...) foram enviadas cartas de apresentação das motivações e intenções da pesquisa. Estas cartas eram enviadas sempre cerca de duas semanas antes das visitas." (498). A atitude dos pesquisadores, faz com que o sujeito de pesquisa seja livre para decidir sobre sua participação. Muitas vezes, o uso de carta de apresentação da pesquisa, e até mesmo de um termo de responsabilidade do pesquisador, onde seja descrito o objetivo e procedimento detalhado da pesquisa, pode ser um instrumento capaz de dar liberdade de decisão ao sujeito de pesquisa.

Em $228(77 \%)$ artigos não encontramos nenhuma citação relativa à autonomia e ao consentimento do sujeito. Este fato, não é em nenhum momento uma afirmativa de que não houve respeito à autonomia do sujeito, ou até mesmo, que o consentimento não tenha sido obtido dos sujeitos pesquisados.

O processo de consentimento é fundamental para a operacionalização da autonomia, buscando sempre o respeito e a dignidade do participante. 
Grande parte dos códigos e resoluções sobre ética em pesquisa é unânime com relação ao consentimento que se embasa no princípio de que indivíduos capazes têm o direito de decidir livremente sua participação em uma pesquisa, respeitando seu livre arbítrio e autonomia. (CIOMS 1993, DECLARAÇÃO DE HELSINQUE 1996, RESOLUÇÃO 196/96 1996)

$\mathrm{Na}$ análise da pesquisa, constatamos uma baixa explicitação da palavra "consentimento". Somente em 13 (4\%) dos 296 artigos científicos que envolviam diretamente sujeitos de pesquisa houve menção ao consentimento. Sendo que, em 9 artigos $(69,136,219,297,319,321,471,500,564)$, que explicitaram o termo "consentimento", não houve menção se o mesmo foi oral ou escrito. Em 2 artigos a forma de consentir foi conforme palavras encontradas nos textos, oral e verbal (249 e 279). Em 2 artigos o consentimento foi por escrito (304, 372). Parte deste resultado, provavelmente, deveu-se ao desconhecimento da então Resolução 01/88 em vigor naquela época, que já trazia em seu escopo a importância do consentimento.

Neste sentido, FREITAS e HOOSNE (1998) afirmam que no primeiro ano de implantação da Resolução 196/96 (de outubro de 1996 a outubro de 1997) foram criados cerca de 150 Comitês de Ética em Pesquisa nas instituições de destaque na pesquisa no país. Evidenciando, assim, um grande avanço em relação a 1995 quando se constatou a existência de tãosomente um Comitê de Ética em Pesquisa constituído conforme a norma vigente à época (Resolução 01/88), dentre instituições universitárias de pesquisa em saúde.

O consentimento para ser válido tem que envolver três elementos básicos. Primeiro: o indivíduo, o grupo ou a comunidade tem que ser competente para entender e avaliar a informação sobre a pesquisa e fazer uma escolha informada. Segundo: o consentimento tem de ser voluntário. A decisão de um futuro sujeito de pesquisa, grupo ou comunidade não deverá 
ser prejudicada por influências que reduzam a liberdade de decisão, como no caso de uma pessoa pobre que aceite participar de uma pesquisa porque Ihe é oferecida uma compensação monetária. Terceiro: um possível sujeito, grupo ou comunidade deverá ter acesso a uma informação detalhada sobre a pesquisa, para que seja possível fazer um julgamento considerável sobre se deve ou não participar da pesquisa. (OSUNTOKUM 1993)

BEAUCHAMP e CHILDRESS (1989) enfocam como elementos do consentimento informado: Informação sobre a pesquisa; entendimento da informação pelo sujeito da pesquisa e/ou responsável; escolha autônoma pelo sujeito da pesquisa e/ou responsável; competência em entender as informações sobre a pesquisa; e finalmente o consentimento ou autorização em estar participando.

Para ilustrar, vejamos o exemplo, de estudo publicado em 1996, realizado para conhecer os determinantes do aborto provocado entre mulheres admitidas em hospitais em localidade da região do nordeste do Brasil, no qual encontramos a seguinte citação: "Antes do início da entrevista, era explicada a natureza do estudo e obtido consentimento para participação na pesquisa (....) nenhuma mulher selecionada para a entrevista se recusou a participar do estudo." (321)

A informação é um fator imprescindível para a elaboração de um consentimento. Quanto mais informações forem disponibilizadas aos sujeitos participantes da pesquisa, melhores condições os mesmos terão para fazer escolhas autônomas. Estas informações devem ser detalhadas e consoantes com a condição de entendimento do sujeito de pesquisa.

HOOSNE e VIEIRA (1995) colocam que a experimentação com seres humanos só pode ser feita mediante consentimento. É o consentimento que transforma o que seria simples uso da pessoa em participação dessa pessoa num empreendimento científico. 
A RESOLUÇÃO 196/96 é precisa sobre esta questão elencando no seu capítulo IV - Consentimento Livre e Esclarecido, alguns elementos que deverão compor um consentimento, afirmando que o respeito à dignidade humana exige que toda pesquisa se processe após consentimento livre e esclarecido dos sujeitos, indivíduos ou grupos, que por si e/ou por seus representantes legais manifestam sua anuência à participação na pesquisa. No seu artigo VI.1, encontramos os procedimentos para se formular um consentimento livre e esclarecido: a exigência de linguagem acessível, sem termos técnicos e que seja entendida pelo sujeito pesquisado; que inclua necessariamente: a justificativa, os objetivos e os procedimentos à serem utilizados na pesquisa; os desconfortos e riscos possível, bem como os benefícios esperados; a liberdade do sujeito se recusar a participar ou retirar seu consentimento, em qualquer fase da pesquisa, sem penalização alguma e sem prejuízo ao seu cuidado; a garantia de sigilo que assegure a privacidade dos sujeitos quanto aos dados confidenciais envolvidos na pesquisa; as formas de ressarcimento das despesas decorrentes da participação na pesquisa, ou seja, despesas com ônibus, gasolina, táxi, alimentação, dentre outras despesas, e as formas de indenização diante de eventuais danos decorrentes da pesquisa, neste caso, deverão ser indenizados sujeitos de pesquisa que sofreram algum dano material, físico ou psíquico decorrente da pesquisa.

Mais importante que o termo escrito é o processo de explicar detalhadamente $\circ$ processo da pesquisa, propiciando uma decisão autônoma do sujeito.

Outro exemplo, de pesquisa publicada em 1994, realizada para promoção da amamentação em localidade urbana da região sul do Brasil: estudo de intervenção randomizado, na qual encontramos o seguinte relato dos autores: "Durante (....) meses (....) todas as mães que tiveram filhos nos hospitais de (....) foram convidadas para participar do estudo (....) mães 
concordaram em participar e após darem o consentimento oral responderam um questionário." (249)

Neste sentido, CLOTET (1995) contribui afirmando que o exercício do consentimento envolve em primeiro lugar uma relação humana dialogante, o que elimina uma atitude arbitrária ou prepotente por parte do médico. Este posicionamento do médico manifesta o reconhecimento do paciente ou sujeito da pesquisa como um ser autônomo, livre e merecedor de respeito. Esclarece o autor, que o consentimento pode ser oral ou escrito, sendo esta última forma a mais recomendável. Apesar do autor se referir ao consentimento no exercício médico, podemos transportar esta afirmação para a prática do pesquisador.

Para LEVINE (1991) o consentimento pode ser conduzido explicando o processo verbalmente. O autor expõe que este tipo de ação apresenta problemas com a documentação do consentimento esclarecido. O processo de consentimento esclarecido é desenvolvido para mostrar respeito para com as pessoas, promovendo o interesse do sujeito de pesquisa através do "empoderamento" para exercer e proteger seus próprios interesses.

Todavia, nem sempre um termo de consentimento significa que houve respeito à autonomia e dignidade do sujeito de pesquisa. VIEIRA e HOOSNE (1987) resumem muito bem esta questão quando colocam que "... é preciso distinguir "formulário de consentimento" de "consentimento". “ (p.134). Em outras palavras, o consentimento é muito mais que uma simples assinatura em um papel concordando em participar ou autorizando a participação de algum sujeito que não esteja apto a consentir por si só.

A Resolução 196/96, afirma que o consentimento deverá ser assinado ou identificado por impressão dactiloscópica, por todos e cada um dos sujeitos de pesquisa ou por seus representantes legais. Propomos outras possibilidades como a leitura e gravação em K-7 do consentimento, ficando 
uma fita para o pesquisador e uma para o sujeitos de pesquisa, abordando oralmente a data do consentimento, explicação detalhada do processo da pesquisa, enfatizando possíveis riscos e benefícios, sigilo e confidencialidade; ou até o mesmo processo em gravação VHS do momento do consentimento. Consentimento verbal com entrega de um termo de responsabilidade do pesquisador responsável, com explicações sobre o processo da pesquisa e dados de identificação, endereço da instituição e formas de contato (telefone, e-mail, bips, celular). Ressaltamos, que os procedimentos deverão ser explicitados no protocolo de pesquisa para a aprovação do Comitê de Ética e informados antes de se iniciar uma gravação, seja ela em K-7 ou VHS, ao sujeitos de pesquisa, para tenham os mesmos, opção de consentir ou não com o método proposto.

Vejamos o que dizem BEAUCHAMP e CHILDRESS (1989) em seu sub-capítulo de funções e justificativas do consentimento. Os autores afirmam que o processo de consentimento deve ter o objetivo de permitir escolhas autônomas de pacientes e sujeitos de pesquisa mas, servem também, para a proteção dos sujeitos contra eventuais riscos e o encorajamento dos pesquisadores para agir responsavelmente em sua interação com pacientes e sujeitos de pesquisa.

Sugere-se que o pesquisador seja sensível as diferenças e tenha discernimento ao elaborar um termo de consentimento. Muitas vezes, o pesquisador pode abusar de sua autoridade e conhecimento ao obter 0 consentimento do sujeito de pesquisa, "bombardeando" o mesmo com uma grande quantidade de informações. (INGELFINGER 1972).

FREUND (1965) afirma que o sujeito de pesquisa nunca deverá ocupar um segundo plano em uma pesquisa. Antes de iniciar uma pesquisa, o pesquisador deverá perguntar a si mesmo: Está o sujeito ciente do que pretendo fazer? Explanei com honestidade os riscos que o mesmo poderá estar correndo? Estou satisfeito e o consentimento foi livre e legalmente 
válido? Este procedimento tomado, seria válido para uma pesquisa que fosse desenvolvida com minha esposa ou filhos? Interessante a indagação de FREUND (1965), pois remete o pesquisador a refletir sobre sua prática, de forma a agir eticamente.

O processo de pedir o consentimento a um sujeito de pesquisa é um exercício mútuo entre o pesquisador e o sujeito - indivíduo, grupo ou comunidade --, cujo principal objetivo é o respeito à autonomia e à dignidade do sujeito da pesquisa, mas pode também ser considerado um processo pedagógico - explicar - entender - construir juntos (pesquisador $\mathrm{x}$ sujeito) a pesquisa. HOSSNE e VIEIRA (1998) afirmam que a obtenção do consentimento esclarecido do sujeito é um processo de negociação que exige respeito aos direitos e à dignidade do paciente, neste caso o sujeito da pesquisa.

FORTES (1998) afirma que de maneira geral, orienta-se que se sejam utilizados como sujeitos de pesquisa preferencialmente as pessoas com autonomia plena, respeitando seus valores éticos-morais, culturais, sociais e religiosos.

\subsection{Idosos}

Encontramos, artigos científicos que envolviam idosos como sujeitos de pesquisa. Os idosos devem ser considerados sujeitos autônomos, a menos que em certo momento da vida tenham perdido a competência de decidir, seja de forma momentânea ou permanente. São considerados idosos, para os efeitos de Lei, as pessoas maiores de 60 anos de idade. (Lei No. 8.842 de 04.01.1994)

Em algumas situações, os idosos são considerados vulneráveis e destituídos de autonomia plena, situações estas que qualquer adulto 
autônomo poderá estar sujeito em algum momento da vida, tais como: internação, coma ou estar em restrição de liberdade.

Conforme cita o NATIONAL HEALTH AND MEDICAL RESEARCH COUNCIL (1992), algumas pessoas merecem atenção especial ao serem incluídas em um projeto de pesquisa, para que se tenha certeza que o consentimento informado seja livre e esclarecido. Ressalta, ainda, que não é possível definir estes sujeitos exaustivamente, mas acrescentando à lista em que constam crianças e pessoas com problemas mentais, pode-se incluir pessoas idosas que tenham capacidade legal, mas que estejam impossibilitados de dar o consentimento livre e esclarecidamente.

LEVINE (1996) expõe que vários autores lamentam o fato de não identificar pessoas idosas como uma população especial para o desenvolvimento de pesquisas. Dentre muitas razões o autor afirma que deva-se evitar danos desnecessários e possíveis esteriótipos, como que poderiam nascer da realização de pesquisas com estes sujeitos. Neste sentido, entendemos que o pesquisador deva ser consciente e reflita sobre os procedimentos da pesquisa, evitando na medida do possível riscos (físicos, psicológicos, morais e/ou sociais), ao participante da pesquisa.

Neste outro exemplo, de pesquisa publicada em 1993, para conhecer o perfil do idoso em área metropolitana na região sudeste do Brasil, tem a seguinte citação: "Dos ... idosos sorteados (...) foram efetivamente entrevistados (....) Do total de entrevistas, apenas (...) responderam parcialmente ao questionário, necessitando da ajuda de parentes." (181). Mesmo sendo os idosos considerados autônomos, muitas vezes, os mesmos insistem em consultar os filhos antes de tomarem qualquer decisão. (LEVINE 1996)

Cabe considerar que os idosos muitas vezes têm dificuldade auditiva, visual, são mais lentos para compreender, exigindo dos pesquisadores, 
despender mais tempo com as explicações, elaborar um termo de consentimento com letras maiores, utilizar um ambiente em que se possa falar alto sem perder a privacidade e evitando possíveis constrangimentos, cuidados estes, que vão além da competência do sujeito.

\subsection{Sujeitos de Pesquisa com Competência Reduzida}

\subsubsection{Crianças e Adolescentes}

Legalmente as crianças e/ou adolescentes são considerados sujeitos de pesquisa com competência e autonomia reduzida, ou seja, supõe-se, que os mesmos não sejam capazes de exercer sua autonomia plena. O Código Civil Brasileiro em seu Art. $5^{\circ}$ - afirma que são absolutamente incapazes de exercer pessoalmente aos atos da vida civil: os menores de dezesseis anos, os loucos de todos os gênero; os surdos-mudos, que não puderem exprimir a sua vontade; os ausentes, declarados tais por ato do juiz.

Crianças são consideradas sujeitos com autonomia reduzida, dependem de seus pais e/ou representantes legal para representá-las. Os representantes legais, são os responsáveis pela criança, os tutores, guardiões. A estas pessoas, devem ser fornecidas todas informações para que seja possível uma decisão esclarecida, visando o maior benefício aos sujeitos estudados.

Neste mesmo sentido, o NATIONAL COUNCIL ON BIOETHICS IN HUMAN RESEARCH (1993) explana que deve haver respeito pelos pais e/ou guardiões e até mesmo pelas crianças em determinar suas próprias respostas a sua participação,.

A permissão dos pais e/ou responsáveis satisfaz o princípio do respeito pela pessoa acatando a necessidade da criança de cuidados e proteção; e por considerar a autoridade dos pais e/ou responsáveis em 
tomar decisões relacionadas à vida de suas crianças (desde que esta autoridade não seja abusiva). Esta posição reflete o parecer tradicional de que os pais e/ou responsáveis tem responsabilidade pelo cuidado e custódia de suas crianças e direitos correlativos a esta responsabilidade. (LEIKIN 1996)

Vejamos o exemplo de pesquisa publicada em 1990, realizada para conhecer os níveis plasmáticos de zinco e antropometria de crianças da periferia de um centro urbano no Brasil. Nela encontramos o seguinte relato: "As famílias foram selecionadas ao acaso, sendo que participaram do estudo aquelas crianças pré-escolares cujos pais permitiram a participação no projeto." (1)

O processo de consentimento, no qual o pesquisador explica os procedimentos da pesquisa aos pais e/ou responsáveis para que os mesmos possam avaliar os riscos e benefícios e consintam a participação da criança, consolida uma prática positiva e respeitosa para o desenvolvimento da pesquisa.

Vejamos o exemplo da pesquisa publicada em 1995, cujo tema versava sobre hipovitaminose $\mathrm{A}$ em crianças de áreas rurais de semi-árido baiano, que traz o seguinte relato: "Após conhecer os objetivos da pesquisa da investigação e os procedimentos para o diagnóstico da deficiência de vitamina $A$, o voluntário responsável pela criança assinou um termo de consentimento e compareceu às escolas das localidade com as crianças em jejum." (304)

Porém, no desenvolvimento de pesquisas com seres humanos, devese considerar, na medida do possível, a vontade destes sujeitos independentemente se são considerados sujeitos legalmente capazes. $\mathrm{O}$ que está em questão é a autonomia de cada um. O critério de competência refere-se a pessoa poder fazer uma escolha, comunicar esta escolha, 
entender uma informação importante a respeito de suas escolhas e alternativas. (Appelbaum e Grisso,1988 citado por WETTSTEIN (1995).

Ainda, neste sentido, o GUIDELINES ON THE PRACTICE OF ETHICS COMMITTEES IN MEDICAL RESEARCH INVOLVING HUMAN SUBJECT (1996), expõe em seu capítulo sobre participantes vulneráveis que crianças mais velhas (o Guia não estabelece a idade padrão) devem ser assumidas como capazes de dar seu consentimento preferencialmente com o consentimento dos pais, representantes legais ou guardiões. Quando a criança for sujeito de pesquisa sua decisão deverá ser respeitada, se a mesma retirar seu consentimento, ou se oferecer resistência em estar participando.

Em pesquisa, publicada em 1995, realizada para conhecer sobre a hipovitaminose $A$ em crianças de áreas rurais de semi-árido baiano, encontramos a seguinte citação que nos chamou a atenção "(....) compareceram 223 crianças para a coleta de sangue; entretanto, não foi possível dosar o (....), porque a quantidade de sangue foi insuficiente ou a criança não colaborou" (304). A criança poderá manifestar sua opção de várias formas: através do medo, choro, reclamação, se movimentado o tempo todo, o importante é que prevaleça sua "opção" sobre a escolha dos pais, vindo ao encontro ao citado pelo NATIONAL COUNCIL ON BIOETHICS IN HUMAN RESEARCH (1993) e pelo NATIONAL HEALTH AND MEDICAL RESEARCH COUNCIL (1992), havendo, também, respeito por parte dos pesquisadores ao aceitarem a recusa da criança.

O ESTATUTO DA CRIANÇA E DO ADOLESCENTE (1991) do seu Título I - Das Disposições Preliminares considera criança para os efeitos desta Lei, a pessoa entre 12 anos de idade incompletos, e adolescente aquela entre 12 e 18 anos de idade. (p.11) 
Na saúde, defende-se para o adolescente a noção de "maioridade sanitária" que se diferencia da "maioridade legal", pela análise da competência decisional do adolescente. É fundamentada no princípio da autonomia, entendendo que, se existe capacidade dos adolescente para tomar decisões, elas devem ser acatadas, independentemente da vontade de pais e responsáveis, garantindo a manutenção da confidencialidade de suas informações, cabendo aos profissionais da saúde, estarem atentos às condições intelectuais e à maturidade emocional do adolescente para apreciar a natureza e as conseqüências de um ato ou proposta da pesquisa. (FORTES e SACARDO 1999).

No desenvolvimento da pesquisa, o adolescente deverá ser representado por seus pais e/ou responsáveis, mas, sempre que possível, deve-se respeitar a decisão do adolescente. Se seus pais consentem, e o adolescente recusa, o pesquisador deverá considerar a recusa do adolescente. Mas em situações consideradas de risco, tais como: riscos psicológicos como, preconceitos e estigmas, riscos à vida, ou à saúde, e frente a realização de pesquisas de maior complexidade, como biópsias e intervenções cirúrgicas, torna-se necessária a participação e o consentimento dos pais e/ou responsáveis. (FORTES e SACARDO 1999).

Vejamos o exemplo de pesquisa publicada em 1996, realizada sobre um programa comunitário de hemoglobinopatias hereditárias em população estudantil brasileira, encontramos o seguinte relato: "Atendendo ao disposto no artigo 123 do Código de Ética Médica, a autorização para a realização de exames laboratoriais foi solicitada por escrito aos estudantes ou, no caso de menores de idade, aos seus responsáveis. Os objetivos da pesquisa, que visam à proteção da saúde pública da comunidade, foram especificados na carta-convite, como rege o artigo 125 do referido Código de Ética Médica. A participação dos estudantes foi voluntária e isenta de qualquer conotação financeira, política, racial ou eugênica."(340) 
Atitudes cuidadosas são importantes no desenvolver da pesquisa, como a preocupação de procurar documentos que embasem a boa prática na pesquisa, mas consideramos, ainda mais relevante, o cuidado em obter uma participação voluntária dos sujeitos de pesquisa, respeitando a escolha de cada um, e que isente o mesmo de possíveis riscos de danos.

\subsubsection{Pessoas com Transtornos Mentais}

Os sujeitos com transtorno mental, apesar de adultos e capazes, podem em algum momento, dentro do processo da doença ter sua autonomia reduzida. Estudos com pacientes psiquiátricos devem ser detalhadamente explicados no protocolo de pesquisa, devendo ser garantido a não exposição destes sujeitos a riscos inapropriados, danos, exploração e terapias inadequadas. (NATIONAL BIOETHICS ADVISORY COMMISSION, 1998).

Neste sentido, afirma FORTES (1994) a abordagem ética se revela mais complexa, pois por um lado qualquer desordem emocional ou mental, e mesmo uma alteração física, pode comprometer a apreciação e a racionalidade das decisões reduzindo a autonomia do sujeito de pesquisa dificultando sobremaneira o estabelecimento de limites precisos de capacidade individual de entendimento, de deliberação, de escolha racional. Neste caso passa a ser necessária a diferenciação da pessoa autônoma com a possibilidade de realização de atos autônomos.

Vejamos o exemplo de pesquisa, publicada em 1996, realizada para conhecer a expectativa da família, ajuste social e diferenças de gênero em uma amostra em paciente esquizofrênicos, encontramos o seguinte relato dos autores: "(....) todos os pacientes de uma clínica sob cuidados psiquiátricos, diagnosticados com esquizofrenia, por ICD (...), clinicamente estabilizados, e portadores da doença há mais de quatro anos foram incluídos no estudo." (341) 
Mesmo diante de tantas dificuldades, e mediante o crescente uso destes sujeitos em pesquisas farmacológicas, clínicas, sociais e de comportamento, deve-se, sempre fazer um esforço em considerar a autonomia destes sujeitos de pesquisa, respeitando sua vontade e maximizando os benefícios pelo menor risco.

Vejamos o exemplo de pesquisa publicada em 1995, um estudo sobre transtorno de humor em enfermaria de clínica médica e validação da escala de medida (HAS) de ansiedade e depressão, encontramos o seguinte relato: "Realizou-se um estudo transversal de prevalência de ansiedade e depressão em pacientes admitidos em uma enfermaria de clínica médica. $A$ avaliação psiquiátrica foi concluída entre 48 - 72 horas após a internação, em duas fases: aplicação do instrumento (....), no período da manhã; realização de entrevista psiquiátrica estruturada (....), no período da tarde do mesmo dia. Dos pacientes internados, sob essa condição, (....) foram excluídos, um que apresentava estado confusional agudo, outro não falava português, um paciente que estava em mau estado geral e dois outros tiveram alta antes que a avaliação psiquiátrica se completasse. Assim, um total de (....) foram avaliados. Não houve recusa da participação." (310)

A citação acima deixa implícita a idéia de que foi pedido o consentimento para participação do sujeito na pesquisa. Consideramos relevante o pesquisador ponderar a abordagem de sujeitos de pesquisa nestas condições, caso o sujeito consinta em participar, sugerimos ao(s) pesquisador(es) que tenham sensibilidade e percepção de qualquer atitude do sujeito que denote impaciência, angústia, mal-estar, para que a coleta de dados seja interrompida, não causando nenhum tipo de dano físico e/ou psicológico. Na impossibilidade de obter o consentimento de sujeitos com transtorno mental, o mesmo deverá ser obtido por pais e/ou responsáveis, sempre esclarecendo todas as fases da pesquisa e a possibilidade retirada do consentimento em qualquer momento da mesma. 


\section{Sujeitos de Pesquisa em Situação de Vulnerabilidade}

Existem sujeitos de pesquisa, que embora adultos e autônomos, merecem atenção especial, pois encontram-se em situação de vulnerabilidade, exigindo do pesquisador maior sensibilidade e reflexão na abordagem destes participantes.

A Resolução 196/96 expõe em seu Capítulo II - Termos e definições - II - vulnerabilidade - refere-se a estado de pessoas ou grupos que, por quaisquer razões ou motivos, tenham a sua capacidade de autodeterminação reduzida, sobretudo no que se refere ao consentimento livre e esclarecido. (p.6)

Considera que no geral, os sujeitos de pesquisa são identificados como vulneráveis quando são relativamente ou absolutamente incapazes de proteger seus próprios interesses, ou seja, eles possuem insuficiente poder, destreza, inteligência, recursos, força e outros atributos requeridos para proteger seus próprios interesses através de negociações por consentimento esclarecido. definem os sujeitos vulneráveis como: os que não compreendem: deficientes mentais, os senis, os de baixa escolaridade e a crianças; estão em situação de dependência: todos os institucionalizados, como prisioneiros, velhos asilados, menores recolhidos em orfanatos e outros tipos de instituição. Também se encontram em situação de dependência os pacientes de enfermaria, os empregados e alunos; pessoas com doenças crônicas, refratárias à terapia conhecida, são vulneráveis porque podem estar procurando ajuda desesperadamente. (HOOSNE e VEIRA 1995, LEVINE 1986). 
Fazem parte dos grupos vulneráveis: índios, subordinados, prisioneiros, menores institucionalizados, estudantes, hospitalizados, usuários de serviço da rede pública de saúde, senis, mulheres de comunidades carentes, (por muitas vezes serem subordinadas aos seus maridos) minorias raciais, populações carentes, pessoas muito doentes, dentre outros. (SWEEMER, Ba 1993, RELATÓRIO BELMONT 1974, GUIA INTERNACIONAL PARA ANÁLISE ÉTICA DE ESTUDOS EPIDEMIOLÓGICOS 1991)

Para GUIMARÃES e NOVAES (1997) a vulnerabilidade nada mais é que uma outra maneira de se olhar o sujeito: pessoas que estão sujeitas a um conjunto de fatores, condições sociais, culturais, educacionais, econômicas e, em certos casos, de saúde que as colocam à margem dos processos produtivos da sociedade onde vivem. Estas pessoas ou grupos, excluídas da sociedade de consumo, os desprivilegiados em países de economia periférica, as etnias culturalmente ou socialmente desfavorecidas em diferentes países ou refugiados políticos ou certos grupos etários têm dificuldade ou mesmo impossibilidade de decidir. Complementando, no caso de sujeitos incapazes de decidir, alguém tomará as decisões em seu lugar, mas tais pessoas serão sempre merecedoras de respeito. Fazer de outro modo seria transformá-los de sujeitos em objetos.

Neste momento estaremos discorrendo sobre sujeitos em situação de vulnerabilidade determinadas por condicionamentos específicos ou influência de autoridade, conforme categoria retirada da resolução 196/96 abaixo citada:

- liberdade do consentimento deverá ser particularmente garantida para aqueles sujeitos que, embora adultos e capazes, estejam, expostos a condicionamentos específicos ou à influência de autoridade, especialmente estudantes, militares, empregados, presidiários, internos, centros de readaptação, casas-abrigo, 
asilos, associações religiosas e semelhantes, assegurando-lhes a inteira liberdade de participar ou não da pesquisa sem quaisquer represálias.

\subsection{Sujeitos Expostos à Condicionamentos Específicos ou à Influência de Autoridade}

Por se tratar de análise de artigos científicos publicados em revistas de saúde pública, grande parte dos sujeitos envolvidos são usuários de equipamentos públicos de saúde*. Certamente, estes sujeitos possuem autonomia, em decidir sua participação em pesquisas, mas de certa forma, cabe ao pesquisador criar possibilidades para que esta escolha seja livre e esclarecida.

Como sabemos se um sujeito de pesquisa está exposto à um condicionamento específico que o torne vulnerável? O que o torna vulnerável? Sua condição social? psicológica? física? Neste sentido, reforçase a responsabilidade do pesquisador na abordagem criteriosa deste sujeito de pesquisa, como discutiremos a seguir.

Em pesquisa publicada em 1994, para conhecer a caracterização da saúde de crianças atendidas em creches e prevenção dos distúrbios de comunicação, encontramos o seguinte relato: "O questionário foi aplicado (...) pelas (...) estagiárias envolvidas no programa de creche que solicitavam à atendente de enfermagem ou diretora da instituição que convocassem os pais das crianças, dando-se preferência a fazer a entrevista com as mães." (226)

Seria recomendável que a solicitação da participação dos pais não partisse da enfermagem ou da direção da instituição, e sim, dos próprios

\footnotetext{
* Equipamentos públicos, são órgãos públicos municipais, estaduais e federais, tais como: hospitais, centros de saúde, centros de referência, creches e escolas.
} 
pesquisadores. Cabe esclarecer que no caso de pesquisas com crianças e/ou responsáveis, usuárias de creches públicas, a diretora deverá consentir somente na realização ou não da pesquisa dentro da instituição, não devendo interferir na autonomia dos pais e/ou responsáveis e até mesmo na escolha da criança, caso a mesma se recuse a participar. Aos pais e/ou responsáveis se deve pedir o consentimento livre e esclarecido, deixando claro que seu consentimento, recusa ou retirada do consentimento dado anteriormente em qualquer momento, não influirá na disponibilização da vaga ou no cuidado da criança dentro da instituição.

Encontramos em pesquisa, publicada em 1990, sobre inquérito sorológico para a detecção de anticorpos contra o vírus da imunodeficiência humana $(\mathrm{VIH})$ em crianças internadas em enfermaria geral de um hospital universitário, o seguinte relato: "na admissão, os acompanhantes dos pacientes responderam um questionário, com o objetivo de identificar fatores de risco para infeção pelo $\mathrm{VIH}$. Os pais dos pacientes assinaram a internação, termo de compromisso, no qual tomavam ciência e se comprometiam a aceitar a realização de exames laboratoriais e procedimentos diagnósticos e terapêuticos que se fizessem necessários para a criança internada." (14)

A prática de assinatura de um termo de compromisso, não garante muitas vezes, o respeito a autonomia do pai e/ou responsável, que, de certa forma pode se sentir coagido a participar da pesquisa para não sofrer nenhum tipo de represália. Muitas vezes, o sentimento de represália vivenciado por sujeitos de pesquisa e/ou responsável pode não ser real. Cabe ao pesquisador ser sensível a possíveis temores, explicando de forma clara e objetiva os procedimentos da pesquisa, bem como, os riscos e benefícios advindos da mesma. 
LEVINE (1989) embasa nossa justificativa ao esclarecer que o uso de sujeitos de pesquisa nestas condições tem provocado temores com relação aos riscos que eles podem correr se recusarem em participar.

A pesquisa científica em seu curso ordinário não é nem má nem racista, mas pode encontrar "material humano" disponível na vulnerabilidade do doente. (PESSINI e BARCHIFONTAINE 1997). Complementamos, que nem somente do doente, mas também, dos institucionalizados, carentes, iletrados e usuários de equipamentos públicos.

Vejamos o exemplo de pesquisa publicada em 1991, realizada com mulheres grávidas para detectar anemia e desnutrição maternas e sua relação com o peso ao nascer, na qual encontramos a seguinte citação: "As mulheres que utilizavam os serviços obstétricos oferecidos pelo (....), entidade de caráter exclusivamente assistencial, são na sua maior proporção aquelas sobre quem recaem condições adversas e pequena disponibilidade financeira e de recursos médico-assistenciais (....) o sangue venoso utilizado para a dosagem foi colhido na sala de pré-parto. (83)

É preocupante a situação da maioria dos sujeitos de pesquisa neste país, que sem acesso assegurado à assistência à saúde muitas vezes buscam a participação na pesquisa como forma de obter acesso a algum tratamento ou o melhor acompanhamento. (FREITAS e HOOSNE 1998)

O fato do sujeito de pesquisa necessitar de atendimento, vaga, consulta, exames, não justifica os pesquisadores de estarem dispondo, de qualquer forma, de material biológico e/ou dados secundários destes sujeitos. A Resolução 196/96 afirma que a utilização de material biológica e os dados obtidos devam ser utilizados exclusivamente para a finalidade prevista em seu protocolo. 
Vejamos o exemplo de pesquisa publicada em 1996, cujo propósito foi conhecer sobre enteroparasitoses em gestantes e puérperas no Rio de Janeiro, encontramos a seguinte citação: "Foram estudadas (....) mulheres com faixa etária entre (....) e (...) anos. Um grupo de (...) gestantes em acompanhamento pré-natal, sendo (....). oriundas de maternidade municipal, e (....) do posto de atendimento médico federal (....) Os potes para a coleta de material foram distribuídos às mulheres como parte da rotina dos exames realizados durante o pré-natal." (556)

Salientamos a necessidade de informar os participantes da pesquisa sobre os procedimentos da mesma, e no caso, de coleta de material biológico e/ou dados secundários, tais como: prontuários, fichas, exames, qual será o propósito e se o mesmo consente que sejam desenvolvidas pesquisas com este material. Estaremos enfocando esta questão no próximo capítulo.

Concordamos com GOSTIN e JORDAN (1992) em seu artigo sobre "Um Guia Anotado para Análise Ética de Pesquisas envolvendo Seres Humanos", ao afirmarem que se grupos vulneráveis, tais como mulheres grávidas e pessoas institucionalizadas, forem sistematicamente excluídas de pesquisas, não poderão receber os benefícios, e os resultados da pesquisa não serão generalizados para estes grupos. $\mathrm{O}$ que alegam os autores é que deverá haver equidade na seleção destes sujeitos. Mas, complementamos, que uma prática ética da pesquisa, requer respeito à dignidade do ser humanos.

No caso de seleção de sujeitos vulneráveis para participação em pesquisas deve-se avaliar detalhadamente o projeto de pesquisa, sendo responsabilidade do Comitê de Ética apreciar os projetos, bem como, desempenhar papel educativo com relação aos sujeitos da pesquisa, à comunidade científica e à sociedade como um todo. (CIOMS 1991, FREITAS e HOOSNE 1998) 
Neste mesmo sentido, cabe ao pesquisador o papel de reconhecer o sujeito de pesquisa como vulnerável ou não, e aos Comitês de Ética em Pesquisa avaliar atentamente os possíveis riscos e injustiças decorrentes de pesquisas com grupos vulneráveis. Bem como, um esforço do pesquisador para reconhecer estes sujeitos vulneráveis como autônomos, embora pertencentes a esta categoria; não descartá-los como de pouca valia e encontrar modos de estabelecer uma ponte entre este(s) sujeito(s) e o pesquisador de modo a decifrar sua vontade. (GUIMARÃES e NOVAES 1997)

Em estudo, publicado em 1993, realizado para conhecer sobre os fatores nutricionais no leite de mães brasileiras que amamentavam bebês, encontramos o seguinte relato dos autores: "Todas as mães deram seu consentimento informado no estudo e o protocolo de pesquisa foi apresentando ao Comitê de Ética do hospital." (219)

Existem pacientes, usuários de equipamentos públicos de saúde, que são pacientes diferenciados devido a suas patologias bem como, aos cuidados especiais decorrentes de suas doenças e ao vínculo sistematizado que os mesmos possuem com certos equipamentos de saúde.

Poderíamos citar várias patologias que compõem a dos pacientes considerados "especiais", somente ilustrando os diabéticos, portadores de HIV, hansenianos, cardíacos, usuários de álcool e outras substâncias, pessoas com transtornos mentais, dentre outros. Acrescentamos, que estes sujeitos são particularmente vulneráveis, não somente devido ao uso de equipamentos de saúde, mas também, da dependência dos mesmos de cuidados especiais. 
HOOSNE e VIEIRA (1995) apontam que são, também considerados vulneráveis, as pessoas com doenças que têm tratamento conhecido, mas necessitam de intervenção especializada para se recuperar.

Em pesquisa, publicada em 1996, desenvolvida para identificar barreiras para aderência ao tratamento da hanseníase encontramos o seguinte relato da autora: “(....) na linha dos estudos de representações sociais, foram feitas com instrumento de coleta de dados, entrevistas individuais, gravadas com o consentimento dos sujeitos(....) O paciente era chamado pela entrevistadora para dirigir-se a um dos consultórios (....) Lá chegando, the era informado sobre a pesquisa (....) e sobre a liberdade que o mesmo tinha de não participar caso assim preferisse, salientando o fato de que sua participação ou não seria ignorada pela equipe médica." (564)

A clareza da abordagem do sujeito, o respeito por suas escolhas, o cuidado com sua privacidade, e o esclarecimento de que as informações colhidas estarão limitadas ao pesquisador, proporciona ao sujeito de pesquisa em situação de vulnerabilidade, sentimento de confiança na relação com o pesquisador.

Para complementar, salientamos LEVINE (1989) que em discussões sobre consentimento expressa que deverá ser claramente explicado aos sujeitos de pesquisa, que estão livres para recusar a participar, bem como, poderão retirar-se da pesquisa a qualquer momento, devendo ser resguardado ao sujeito que sua recusa ou retirada não criará nenhum tipo de embaraço ou dano à sua futura relação com o investigador ou instituição.

\subsection{Empregados}

Trabalhadores são sujeitos de pesquisa que embora autônomos, capazes e geralmente maiores de idade podem estar expostos a 
condicionamentos específicos ou à influência de autoridade e em alguns momentos estarem expostos a situações de vulnerabilidade.

O RELATÓRIO BELMONT (1978) considera que a seleção de sujeitos de pesquisa deve ser examinada minuciosamente para determinar se algumas classes são selecionadas sistematicamente devido à sua fácil disponibilidade, ou à sua posição compromissada, sua fácil manipulação, mais do que as razões diretas relacionadas ao estudo em questão.

Vejamos a pesquisa, publicada em 1993 realizada para conhecer a representação dos riscos à saúde na indústria petroquímica, encontramos o seguinte relato: "A pesquisa foi realizada ao longo dos anos de (....) a (....) quando foi obtido o consentimento da empresa para observar o processo de trabalho, estudar o processo produtivo e os riscos nele implicados e entrevistar os trabalhadores(....) Os encontros se deram no interior da empresa, onde obtivemos o consentimento para realizar as entrevistas com a liberação dos trabalhadores." (451).

O relato mostra que houve consentimento da empresa representada por seu superior. Mas em nenhum momento, ficou claro, se houve o consentimento do empregado em participar. No caso de pesquisas desenvolvidas em locais de trabalho, deverá primeiramente o pesquisador pedir autorização dos responsáveis pelo local para o desenvolvimento da pesquisa, e após o consentimento do responsável, os funcionários deverão consentir na participação individualmente, respeitando suas escolhas, sem que as mesmas tragam qualquer tipo de constrangimento ou represália, por parte de seus superiores. Sugerimos que o contato seja efetuado em um sala privativa, onde possa ser resguardada a privacidade e a confidencialidade das informações.

Em pesquisa, publicada em 1992 sobre síndrome dos edifícios doentes em bancários, os autores colocam: "Com a devida autorização das 
empresas e concordância dos trabalhadores foi distribuído questionário para ser respondido pelos trabalhadores" (166).

Em outro exemplo, de pesquisa, publicada em 1991, sobre doenças sexualmente transmissíveis: conceitos, atitudes e percepções entre os coletores de lixo, encontramos o seguinte relato: "(....) estabeleceu-se data e horário para a realização das entrevistas, de tal forma a não prejudicar o andamento do serviço e nem o horário de saída destes trabalhadores. Foram incluídos todos os sujeitos que estavam presentes na data estabelecida para entrevista, que concordaram em participar da mesma(....)" (87)

Apesar de considerarmos as práticas acima citadas como eticamente adequadas na abordagem de sujeitos de pesquisa, consideramos importante que os mesmos sejam informados que a recusa em participar e a retirada da pesquisa a qualquer momento não acarretará nenhum prejuízo, tais como represálias por parte de superiores.

Cabe citar o exemplo de pesquisa publicada em 1991 sobre considerações metodológicas na interpretação do rastreamento sorológico da hepatite B em doadores de sangue: “(...) foram excluídos indivíduos que se apresentavam em grupos pertencentes a uma mesma empresa, e militares, devido à dificuldade de se estabelecer a espontaneidade dessas doações." (63)

É importante que o pesquisador seja perspicaz e não abuse da condição do sujeito de pesquisa, para que o mesmo não se sinta induzido a participar de uma pesquisa por estar em situação de vulnerabilidade. Para tanto, mais uma vez enfatizamos o processo de consentimento, o qual possibilitará que o sujeito de pesquisa faça sua opção autonomamente e livremente. 


\subsection{Prisioneiros e Menores Institucionalizados}

Apesar de serem adultos, os prisioneiros são considerados sujeitos vulneráveis por estarem em restrição de liberdade. Esta condição não exime o direito destes sujeitos de pesquisa em exercer sua autonomia e decidir se querem ou não participar de qualquer tipo de estudo. Possuem os mesmo direitos à informação e ao esclarecimento, devendo sua decisão voluntária ser respeitada e isenta de qualquer sanção.

BEAUCHAMP e CHILDRESS (1989) colocam que é especialmente importante assegurar que o direito à autonomia seja preservado em instituições cuja população é admitida involuntariamente. Não existe razão de prisioneiros, por exemplo, não terem seu consentimento validado para uma pesquisa se táticas coercitivas não forem especificamente envolvidas e se não tiver nenhum tipo de manipulação, tais como o oferecimento de um excessivo valor em dinheiro para um experimento de alto-risco. Um ambiente coercitivo não faz uma pessoa se tornar incompetente ou fazer escolhas involuntárias. As pessoas podem estar em situação de vulnerabilidade podendo agir involuntariamente, mas cada caso, individualmente requer uma investigação cuidadosa.

LEVINE (1989) expõe alguns questionamentos com relação à seleção destes sujeitos de pesquisa. O autor coloca as seguintes questões: São os prisioneiros capazes de exercer livre poder de escolha? São capazes de um real consentimento voluntário? Serão destinados aos prisioneiros os benefícios da pesquisa?

Vejamos o exemplo, de pesquisa, publicada em 1990, cujo estudo era sobre a soroprevalência e fatores de risco para a infecção pelo vírus da hepatite B pelos marcadores AgHBs e Anti-HBs e, prisioneiros e primodoadores de sangue, encontramos o seguinte relato: "Foram 
estudados (....) prisioneiros(....) Esses indivíduos foram selecionados aleatoriamente (....) Apenas (....) detentos recusaram-se a participar do estudo, alegando receio da coleta de sangue."(35)

Concordamos que existem dificuldades relativas ao exercício de autonomia destes sujeitos de pesquisa, mas o pesquisador deverá esforçarse para que o processo de consentimento seja efetuado, sem induções e coerções. Neste contexto, a autorização para o desenvolvimento da pesquisa deverá ser pedida ao responsável pela instituição, o consentimento dos presos deverá ser obtido individualmente, explicando todos os pormenores da pesquisa, riscos e benefícios, garantindo o anonimato e a confidencialidade da informação. Apesar das dificuldades encontradas para a realização de pesquisas no espaço físico destas instituições, deverá o pesquisador se empenhar em conseguir uma sala privativa, na qual o presidiário possa ter liberdade e privacidade em estar colaborando com a pesquisa. Consideramos importante o pesquisador ressaltar que as informações colhidas serão restringidas ao pesquisador e/ou equipe, não sendo as mesmas disponibilizadas à nenhuma outra pessoa que não tenha relação direta com a pesquisa.

E quem são os menores institucionalizados? ESTATUTO DA CRIANÇA E DO ADOLESCENTE (1991) em se seu Título IV - Das Medidas Sócio-Educativas, Seção I - Disposições Gerais, que após verificada a prática de ato infracional, conduta descrita como crime ou contravenção penal, a autoridade competente poderá aplicar ao adolescente as seguintes medidas: advertência; obrigação de reparar o dano; prestação de serviços à comunidade; liberdade assistida; inserção em regime de semiliberdade e internação em estabelecimento educacional. (p.35)

No caso de adolescentes em condições de internação em estabelecimento educacional deverão ser informados sobre os procedimentos da pesquisa, possíveis riscos e benefícios, para que seja 
possível uma escolha livre e autônoma. Caso possuam pais e/ou responsáveis, os mesmos deverão ser consultados e informados da pesquisa. Cabe à instituição consentir somente no desenvolvimento da pesquisa, não devendo interferir na decisão dos menores e/ou responsáveis. Em caso de conflito de interesse, havendo consentimento dos pais e/ou responsáveis e instituição e recusa do menor, deverá prevalecer a decisão do adolescente ou criança sem que Ihe recaia qualquer tipo de ônus ou prejuízo.

Com relação aos menores institucionalizados, encontramos pesquisa publicada em 1995, desenvolvida para saber o grau de informação, atitudes e representações sobre o risco e a prevenção da AIDS em adolescentes pobres do Rio de Janeiro, Brasil: "Os locais onde foram desenvolvidos os trabalhos eram de dois tipo: escolas abertas à comunidade e escolas fechadas em regime de internato carcerário para menores infratores (....) As entrevistas foram voluntárias (....). Os estudantes foram informados de seu direito de não responder, assim como, sobre o uso das informações coletadas."(517)

Fica implícito a autonomia dos sujeitos de pesquisa, no momento que se coloca que a entrevista foi voluntária. Consideramos importante o fato dos pesquisadores informarem aos sujeitos de pesquisa qual será o uso das informações coletadas, demonstrando respeito e valorizando a participação do sujeito de pesquisa.

\section{Comunidades Culturalmente Diferenciadas inclusive Indígenas}

- Em comunidades culturalmente diferenciadas, inclusive indígenas, deve-se contar com a anuência antecipada da comunidade através dos seus próprios líderes, não se dispensando, porém, esforços no sentido do consentimento individual.". 
Pesquisas desenvolvidas com esta população, normalmente, devem ter relação direta com o problema destes sujeitos, fazendo-se necessário ter cuidado redobrado, para que os riscos individuais e sociais sejam menores que os benefícios esperados.

MARINER (1993) considera-se uma comunidade vulnerável devido a impossibilidade de consentir voluntariamente, ou por estar em risco de serem exploradas. Para o autor, populações estão em risco de serem exploradas, não porque são incapazes de darem o seu consentimento (embora, algumas populações tenham este problema), mas porque algumas pesquisas as utilizam como um meio para um fim, e normalmente, são usadas de forma injusta e desrespeitosa. O autor, segue afirmando que comunidades rurais, não-industrializadas e iletradas em países em desenvolvimento são, talvez, os exemplos mais citados de populações exploráveis. E mesmo em países desenvolvidos, populações pobres ou comunidades rurais com acesso limitado aos frutos do desenvolvimento, podem também, ser qualificadas como populações exploráveis. (MARINER 1993)

GUIMARÃES e NOVAES (1997) consideram que comunidades ou grupos sociais merecem igual respeito em suas decisões. Entretanto, na sociedade complexa, urbana, em que vivemos, as decisões raramente são unânimes e são geralmente atingidas após um longo processo de discussão e de negociação.

O NUFFIELD COUNCIL ON BIOETHICS (1999) afirma em seu capítulo sobre consentimento para participação em pesquisa que os pesquisadores devem adotar medidas para garantir a informação fornecida, para que a mesma seja apropriada, permitindo que os possíveis participantes consintam em participar. Estas medidas incluem 0 desenvolvimento de um processo interativo, obtendo-se uma identificação do 
local, qual a percepção da comunidade sobre a doença e o tratamento através de discussões com a população a ser estudada.

Vejamos a pesquisa publicada em 1994, desenvolvida para conhecer sobre a evolução nutricional de menores de 5 anos em aldeias indígenas da Tribo Parakanã, na Amazônia Oriental brasileira (1989-1991). Encontramos o seguinte relato: "A população em estudo foi constituída pela população de menores de 5 anos existentes nas aldeias Maroxewara e Paratininga (....) Em cada aldeia, uma enfermeira e uma técnica em enfermagem foram instruídas a prestar serviços de assistência curativa e preventiva (....) um médico sanitarista orientava as atividades de campo via rádio ou em visitas áreas. (221)

Não foi possível, através do relato, se conhecer o processo de consentir. Em alguns casos o consentimento para participar é obtido pelo grupo, organização ou comunidade, e indivíduos se tornam sujeitos de pesquisa sem seu consentimento explícito. (GLANZ et al 1996, CIOMS, 1991)

Em exemplo de pesquisa publicada em 1992, realizada para detectar anemia em população de área endêmica de malária, Rondônia (Brasil), encontramos o seguinte relato dos autores: "Uma amostra aleatória (....) dos domicílios de Candeia foi visitada, escolhendo amostras sangüíneas dos habitantes presentes no momento da visita, perfazendo (....) independente da condição de saúde ou estado fisiológico. Após consentimento informado (de cada paciente ou de seus responsáveis), os indivíduos foram submetidos à (....) simultaneamente, todos foram indivíduos foram submetidos a entrevista (....)" (136)

No editorial do CADERNOS DE ÉTICA EM PESQUISA (1998), Munõz defende que, por se tratar de grupos com culturas e estruturas sociais diferentes, os princípios da bioética devem ser norteadores dos 
estudos realizados junto a estas populações. Para o autor, deve-se levar em conta os diferentes aspectos de cada povo que se pretende estudar, sem que se imponham normas e condutas não pertinentes à comunidade pesquisada.

Comunidades rurais possuem características próprias. Ao pesquisar estas comunidades deverá o pesquisador estar atento para não interferir em seus costumes e culturas e estar sensível às falas, dialetos, quando da obtenção do consentimento destes sujeitos de pesquisa.

Vejamos o relato de pesquisa, publicada em 1996, desenvolvida para conhecer a prevalência do uso de métodos contraceptivos de anticoncepcionais orais na cidade de Pelotas, Rio Grande do Sul, Brasil, encontramos a seguinte citação: "Foram sorteados (...) setores censitários na Zona Rural de Pelotas(....) Coletaram-se informações sobre o método anticoncepcional utilizado, idade das mulheres, classe social, nível de escolaridade, tabagismo, presença de hipertensão arterial sistêmica, e também sobre quem indicou o método." (552)

Mesmo em pesquisas cujo risco seja mínimo aos seus participantes, existe a necessidade do consentimento, mesmo que verbal dos sujeitos de pesquisa. Se estivéssemos analisando um protocolo de pesquisa e não um artigo científico, consideraríamos a necessidade de (i) explicar porque o uso desta população, (ii) em caso de demanda decorrente da pesquisa como: informações sobre medicamentos anticoncepcionais, dúvidas com relação ao medicamento, necessidade de consulta e/ou tratamento, dentre outras possibilidades, como seria trabalhada a mesma? (iii) como seria retornado o resultado da pesquisa às participantes?

Os pesquisadores são responsáveis pelos participantes envolvidos na pesquisa, e os objetivos da pesquisa serão sempre secundários ao bemestar dos participantes. (ANGELL 1999). 
Em pesquisa, publicada em 1992, estudo desenvolvido para conhecer a prevalência de marcadores sorológicos de hepatite $B$ numa pequena comunidade rural do Estado de São Paulo, Brasil, encontramos o seguinte relato: "Toda a população de Cássia dos Coqueiros foi inicialmente visitada (....), os indivíduos cadastrados e com idade igual ou superior a um ano foram chamados ao centro de saúde daquele município (....) para que, caso desejassem, fossem incluídos no estudo após tomarem conhecimento dos seus objetivos e dos procedimentos que seria adotados." (131)

BEAUCHAMP et al (1991) afirmam que em pesquisas epidemiológicas envolvendo sujeitos de outras culturas ou sujeitos de populações vulneráveis é essencial uma especial precaução para proteger o bem estar destes sujeitos, especialmente se eles tiverem limitado controle de seus destinos ou tiverem menos informação do que a usualmente disponível para estes sujeitos.

Outro relato que mostra a disponibilidade dos pesquisadores em respeitar a decisão dos participantes é encontrado na pesquisa, publicada em 1995, sobre Prevalência de Hipovitaminose A em crianças das Periferia do Município de Campinas, São Paulo, Brasil: "Em cada favela sorteada (....) foram sorteadas (...) famílias, para o total de (....) crianças (....) Para casa domicílio visitado foi feito esclarecimento às famílias sobre objetivos e finalidades da pesquisa." (492)

Percebemos um esforço dos pesquisadores em estar respeitando a escolha dos sujeitos de pesquisa. O NATIONAL BIOETHICS ADVISORY COMMISSION BETHESDA (2000) afirma que apesar das possíveis barreiras para adequar o entendimento dos sujeitos de pesquisa, os pesquisadores geralmente são capazes de criar medidas para ultrapassar estas barreiras se realmente eles desejarem, devotando, assim, tempo e esforços. 
O desenvolvimento de pesquisas, cujas práticas sejam éticas, podem ser consideradas trabalhosas para o pesquisador, mas por outro lado, estimula uma interação, diálogo e interesse mútuos, principalmente quando respeitada a autonomia do sujeito através do consentimento livre e esclarecido.

O próximo capítulo trata da confidencialidade, privacidade, proteção da imagem e não estigmatização dos sujeitos de pesquisa, questões consideradas importantes para o desenvolvimento de uma pesquisa ética. 


\section{Confidencialidade - Privacidade - Proteção de Imagem e Não - Estigmatização}

- Prever procedimentos que assegurem a confidencialidade e a privacidade, a proteção da imagem e a não estigmatização, garantindo a não utilização das informações em prejuízo das pessoas e/ou comunidades, inclusive em termos de auto-estima, de prestígio e/ou econômico-financeiro

A CONSTITUIÇÃO DA REPÚBLICA FEDERATIVA DO BRASIL (1988) afirma em seu Art. $5^{\circ}-X$ - são invioláveis a intimidade, a vida privada, a honra e a imagem das pessoas, assegurando o direito a indenização pelo dano material ou moral decorrente de sua violação.

Confidencialidade é a proteção contra revelação não autorizada de informação. (STEVENSON et al 1993)

Privacidade é a obrigação de respeitar os direitos das pessoas de determinar quais sentimentos, pensamentos e emoções deverão ser comunicados à outros. Privacidade, também inclui proteção de intromissão não desejada e da divulgação de informações pessoais para outros. (HAHN 1994)

Proteção de imagem tem relação direta à publicação de artigos científicos, publicações eletrônicas (Internet), vídeos cirúrgicos, aulas, apresentações em congressos e seminários. Estes procedimentos devem ser autorizados mediante consentimento especial, elaborado para este propósito, no início da pesquisa e ao final da mesma, ou seja, o sujeito de pesquisa e/ou responsáveis em caso de menores ou pessoas com autonomia reduzida que não tenham condições de estarem consentindo por si mesmos, deverão ser informados quando houver a necessidade de tirar fotos, filmar, gravar, no início da pesquisa. No final da pesquisa deverão 
confirmar o seu consentimento para a utilização deste material para qualquer propósito -- congressos, publicações, vídeos etc. --. Poderá o sujeito de pesquisa, retirar seu consentimento em qualquer momento da elaboração das fotos. É muito importante que pesquisadores sejam conscientes e esclareçam com clareza os objetivos das fotos, bem como, o veículo de circulação, pois torna-se muito difícil a retirada de uma imagem quando a mesma estiver em domínio público.

A violação da proteção da imagem, da privacidade e da confidencialidade, podem trazer estigmas ao indivíduos, grupos e/ou comunidades estudadas. Por isso os epidemiologistas devem estar conscientes e sensíveis para os sentimentos de indivíduos e grupos, e devem evitar ações desnecessárias que possam causar danos tais como invasão de privacidade e violação da confidencialidade. Esta conduta deverá ser adotada por qualquer profissional que trabalhe com pesquisa. (HOOD et al 1998, LAST 1996)

Vejamos o exemplo desta pesquisa, publicada em 1991, realizada para conhecer a opinião sobre AIDS e possíveis mudanças e comportamento de heterossexuais masculinos: "(...) a escolha do questionário, como instrumento, se deu pelo fato de que possibilita abrangência maior de informações(....), ao mesmo tempo em que garante o anonimato(....) A aplicação do questionário se deu individualmente, não havendo identificação do sujeito, exceto quando por manifestação espontânea do mesmo." (401)

Neste outro exemplo, retirado de uma pesquisa, publicada em 1995, realizada para conhecer o grau de informação, atitudes e representações sobre o risco e a prevenção de AIDS em adolescentes pobres do Rio de Janeiro, Brasil, encontramos o seguinte relato dos pesquisadores: "As entrevistas foram voluntárias, anônimas, individuais e confidenciais. Os 
estudantes foram informados do seu direito de não responder, assim como, sobre o uso das informações coletadas." (517).

A AIDS, uma doença estigmatizante e de difícil abordagem em pesquisas, requer cuidados extras com relação ao sujeito de pesquisa para que seja possível evitar riscos de danos psicológicos, sociais e morais. $\mathrm{O}$ advento da AIDS tem oferecido aos pesquisadores de diversas áreas uma grande reflexão sobre problemas de confidencialidade, privacidade, proteção de imagem e estigmas. Muito tem sido discutido e muitas dúvidas ainda permanecem.

Basicamente, todas as resoluções sobre ética em pesquisa, tanto nacionais quanto internacionais, são unânimes com relação ao caráter confidencial dos dados e as conseqüências que a quebra destes dados podem gerar. Afirma-se que uma maneira de demonstrar o respeito ao direito à privacidade é a obtenção do consentimento informado antes de revelar os dados obtidos durante o curso da pesquisa e reduzir ao mínimo possível a possibilidade de quebra do caráter confidencial dos dados. (CIOMS 1996)

Toda pesquisa deve envolver coleta e armazenamento de dados. Também com relação a estas ações devemos prever a confidencialidade dos dados e informações levantadas dos sujeitos de pesquisa. Pesquisadores devem ser cuidadosos ao estarem armazenando estes dados, para que não ocorram danos aos sujeitos, grupos ou comunidades estudadas.

McCARTHY (1991) afirma que devem ser protegidos os direitos e o bem estar dos sujeitos de pesquisa, com relação aos dados que são coletados. As informações a serem coletadas deverão, na medida do possível, serem apresentadas aos potenciais sujeitos de pesquisa, descrevendo o tipo de dado à ser coletado, as pessoas que terão acesso a 
estes dados, como serão resguardados os dados contra usos indevidos, garantindo que a publicação dos resultados aparecerá somente em forma condensada, a qual não poderá ser relacionada aos sujeitos de pesquisa individualmente, e descrever riscos possíveis no caso de revelação dos dados.

Vejamos, esta pesquisa, publicada em 1991, desenvolvida para conhecer o consumo de substâncias psicoativas entre estudantes da rede privada: "Durante o controle pessoal eram apresentadas as credenciais, explicava-se os propósitos da pesquisa e então eram marcadas as datas de coleta dos dados, garantindo a confidencialidade às escolas." (79)

Posturas como a garantia da confidencialidade e privacidade não afetam o desenvolvimento da pesquisa, demonstrando respeito para com os sujeitos de pesquisa.

O CIOMS (1991) divide as informações obtidas dos sujeitos em informações desvinculadas, que não podem ser associadas ou conectadas ao sujeito que a respondeu, e informações vinculadas, as quais são considerados os seguintes aspectos: informação anônima, - que não pode ser vinculada às pessoa que a respondeu, nem mesmo o investigador sabe identificar a pessoa respondente; não nominal - quando a informação poderá ser vinculadas às pessoas por um código, não incluindo identificação pessoal; nominal ou nominativa, quando a informação é vinculada a pessoa através identificação pessoal, normalmente o nome.

Em pesquisa, publicada em 1995, elaborada para conhecer sobre a decisão de abortar: processo de sentimentos envolvidos, encontramos o seguinte relato dos autores: "Não foi pedida nenhuma informação que permitisse identificar quem respondeu o questionário, garantindo, assim o sigilo." (493) 
Muitos autores e códigos utilizam indistintamente os termos sigilo e segredo. A palavra segredo pode ter o significado de mera ocultação ou de preservação de informações. Os segredos dizem respeito à intimidade da pessoa, portanto devem ser mantidos e preservados adequadamente. A palavra sigilo tem sido cada vez menos utilizada. A sua utilização em diferentes idiomas tem caracterizado cada vez mais os aspectos de ocultação e menos o de preservação. (FRANCISCONI e GOLDIN 1998)

Vejamos o exemplo, da pesquisa, publicada em 1996, também sobre o aborto, em que encontramos a seguinte citação: "Todas as informações eram estritamente confidenciais e sempre que possível era mantido o anonimato (...) As entrevistadas foram conduzidas de forma tão privada quanto possível e em horários convenientes para a mulher durante sua permanência no hospital." (321)

Em outra pesquisa, ainda sobre o tema aborto, publicada também em 1996, desenvolvido para estudar as dificuldades para obter informações da população de mulheres sobre o aborto legal, encontramos o seguinte relato dos autores: “(...) para assegurar o sigilo da fonte de informações, os questionários foram identificados apenas com um número.(369)

O respeito para com os participantes é fundamental no desenvolvimento da pesquisa. A garantia de um lugar privativo, medidas como resguardar o sigilo, anonimato e confidencialidade das informações, garante a cumplicidade e a segurança na relação do sujeito de pesquisa com o pesquisador.

\subsection{Pesquisas Utilizando Dados Secundários}

Entende-se por pesquisas com dados secundários: aquelas realizadas com coleta de dados estatísticos, dados retirados de pesquisas anteriormente desenvolvidas, levantamento de informações em documentos 
provenientes de órgãos públicos, prontuários hospitalares, e material biológico anteriormente colhido e armazenado.

Gostaríamos de pontuar duas pesquisas. A primeira, publicada em 1996, tem como tema distúrbios a situação epidemiológica da turbeculose infantil no município do Rio de Janeiro, na qual encontramos a seguinte citação: "Com base na ficha de notificação de casos, foram levantadas informações pertinentes às seguintes variáveis: idade, sexo, forma clínica da doença e exames complementares, local de atendimento (....)" (565)

A conduta adotada na pesquisa preserva a privacidade e a confidencialidade do sujeito. Importante ressaltar que muitas vezes a coleta de dados envolve uma decisão técnica, como a economia de espaço e a alimentação do banco de dados. Não existe uma orientação com relação ao levantamento estatístico, de quais dados deveriam ser colhidos, sendo uma decisão puramente técnica e não um cuidado ético, cabendo ao pesquisador estar atento a possíveis dados que poderão violar a confidencialidade e a privacidade do sujeito de pesquisa. Consideramos importante, que todos os profissionais envolvidos na pesquisa estejam cientes deste cuidado ético, podendo, o pesquisador responsável discutir com a equipe e com outros profissionais condutas para a melhor prática ética.

Vejamos este outro exemplo, retirado de uma pesquisa, publicada em 1992, elaborada para pesquisar o padrão das lesões nas vítimas de acidentes de motocicleta: "O material de estudo foi composto pela totalidade dos pacientes internados no Hospital das Clínicas da Faculdade de Medicina da Universidade de São Paulo (HVFMUSP) (....) Em ficha própria foram anotados os dados de identificação do paciente (nome, idade, sexo, estado civil, ocupação, local de nascimento e de residência)." (153)

No desenvolvimento de pesquisas, sejam elas com abordagem direta ao sujeito de pesquisa ou coleta de dados secundários, consideramos que 
as informações levantadas tenham relação direta ao objetivos proposto(s). Informações, principalmente as que identificam o sujeito de pesquisa, deverão ser suprimidas, a menos que estas informações como endereço residencial, sejam necessárias, para o envio dos resultados da pesquisa, ou comunicação de algum fato relevante para o sujeito pesquisado, independente da forma de abordagem - direta ou indireta

No caso de acesso a informações que possibilitem localizar o sujeito de pesquisa, o pesquisador deverá, na medida do possível, obter o consentimento do sujeito para o uso dos dados. Reconhecemos, muitas vezes, a dificuldade de ações como esta, mas na possibilidade de sua realização, deverá o pesquisador se empenhar para colocá-la em prática. $\mathrm{Na}$ impossibilidade de contatar o sujeito de pesquisa, deverá o pesquisador e a equipe tomar todas as providências, como a autorização da instituição detentora dos dados, adotando medidas para que não seja violado o princípio da confidencialidade e da privacidade.

DOYAL (1997) considera que sujeitos de pesquisa deveriam consentir no acesso de seus dados; eles deveriam receber informações apropriadas referentes a quem vai utilizá-los e como será mantida a confidencialidade.

Para finalizar, GOLD (1996) expõe que o acesso a dados secundários de pesquisa tem levantado novos desafios com relação à proteção da confidencialidade e da privacidade em estudos epidemiológicos. Continua a autora que tais desafios estão presentes nos recentes estudos tais como o aumento da prevalência da AIDS e na gravidez na adolescência interesse científico em desordens mentais e em idosos, efeitos adversos da exposição ocupacional, proliferação de agentes químicos e físicos sem experimentação prévia de longa duração sobre a saúde humana, diversidade étnica e cultural na população, reforma dos cuidados de saúde e os segredos do genoma humano. 
O tratamento ético de dados secundários é importante para 0 resultado da pesquisa e para os participantes da mesma. Devemos atentar a esta prática, garantindo a privacidade, anonimato e confidencialidade das informações coletadas. Muitas vezes, informações pessoais, ou de locais onde foram desenvolvidas pesquisas, podem afetar diretamente os sujeitos cujos dados foram utilizados, bem como, trazer riscos de danos como estigmas, danos morais e/ou econômicos. 


\section{Análise do Retorno dos Benefícios decorrentes da Pesquisa}

- Garantir que as pesquisas em comunidades, sempre que possível, traduzir-se-ão em benefícios cujos efeitos continuem a se fazer sentir após sua conclusão. O projeto deve analisar as necessidades de cada um dos membros da comunidade e analisar as diferenças presentes entre eles, explicitando como será assegurado o respeito às mesmas.

O NATIONAL BIOETHICS ADVISORY COMMISSION (1998) expõe que pesquisas envolvendo sujeitos de pesquisa poderão produzir três tipos de benefícios potenciais: (1) benefícios diretos aos sujeitos de pesquisa; (2) benefícios indiretos aos sujeitos de pesquisa; e (3) benefícios para outros.

A Resolução 196/96, em seu capítulo V. Riscos e Benefícios, artigo V.2 é clara em colocar "As pesquisas sem benefício direto ao indivíduo, devem prever condições de serem bem suportadas pelos sujeitos da pesquisa, considerando sua situação física, psicológica, social e educacional." (p.11)

Esta categoria nos traz a questão da justiça em pesquisas. A justiça conforme afirma a RESOLUÇÃO 196/96 (1996) "é a relevância da pesquisa com vantagens significativas para os sujeitos da pesquisa e minimização do ônus para os sujeitos vulneráveis, o que garante a igual consideração dos interesses envolvidos, não perdendo o sentido de sua destinação sóciohumanitária (justiça e eqüidade)."

Neste sentido, o RELATÓRIO BELMONT (1974), considera que existem várias formas de distribuição de riscos e benefícios. Estas formas são: (1) uma divisão igual para cada pessoa; (2) para cada pessoa de 
acordo com as suas necessidades individuais, (3) para cada pessoa de acordo com o seu esforço individual, (4) para cada pessoa de acordo com a contribuição social, e (5) para cada pessoa de acordo com o mérito.

Os benefícios devem ser definidos como "bens" ou como "vantagens", os quais produzam "bem-estar", devendo os sujeitos de pesquisa usufruir dos benefícios da mesma, bem como os benefícios devem ser assumidos de uma forma específica, como a continuidade de um tratamento, acesso a um medicamento, sendo este tipo de benefício, normalmente, motivado por uma relação especial entre pesquisadores e sujeitos de pesquisa. (NATIONAL COUNCIL ON BIOETHICS IN HUMAN RESEARCH 1993, LaVERTU e LINHARES 1990, NATIONAL BIOETHICS ADVISORY COMISSION 2000)

Várias são as possibilidades de uma pesquisa ser relevante: a criação nova fórmula medicamentosa, um nova terapia, uma postura diferente dos profissionais de saúde com relação aos paciente hospitalizados, a elaboração de um programa decorrente dos resultados da pesquisa, o retorno da pesquisa à comunidade estudada, o treinamento de pessoas da comunidade para disseminarem os resultados da pesquisa, dentre muitos outros. Ressaltamos que a publicação dos resultados da pesquisa também é uma prática relevante. Pesquisas podem muitas vezes não trazer benefícios diretos aos sujeitos de pesquisa, mas os resultados encontrados podem colaborar com a comunidade científica, trazendo um novo conhecimento científico ou até mesmo confirmando resultados anteriores, fazendo-se importante publicar os resultados, sejam eles positivos ou negativos.

Estaremos dividindo os benefícios decorrentes da pesquisa em dois tipos: Benefícios diretos aos sujeitos de pesquisa, e benefícios institucionais. 


\subsection{Benefícios Diretos aos Sujeitos de Pesquisa}

Encontramos alguns exemplos de pesquisas que ocasionaram benefícios diretos aos sujeitos de pesquisa. Coincidentemente, a maioria das pesquisas foram realizadas com crianças.

Vejamos, o exemplo de pesquisa, publicada em 1994, realizada sobre terapêutica com doses profiláticas de sulfato ferroso como medida de intervenção no combate à carência de ferro em crianças atendidas em unidades básicas de saúde, encontramos o seguinte relato: "As crianças que apresentavam qualquer suspeita de doença eram encaminhadas aos serviços médicos do centro de saúde de cada região." (268)

Neste, outro exemplo, trata-se de uma pesquisa publicada em 1990, elaborada para se levantar os aspectos educacionais da intervenção em helmitoses intestinais, no subdistrito de Santa Eudória, município de São Carlos. Encontramos o seguinte relato dos pesquisadores: "Esses escolares foram submetidos aos seguintes procedimentos (....) para determinação de ...As crianças com resultados parasitológicos positivos foram submetidos ao tratamento específico." (391)

E, por último, pesquisa publicada em 1992 sobre avaliação da ingestão dietética de cálcio em indivíduos adultos portadores de hipertensão arterial idiopática: "Os nutricionistas orientaram todos os indivíduos quanto à redução da ingestão de sal e de gordura de origem animal, e quanto ao aumento do consumo de alimentos ricos em fibras."(120).

Sabemos que muitas vezes é impossível prever possíveis demandas, sejam elas físicas, psicológicas e/ou sociais, decorrentes de pesquisas já realizadas ou em desenvolvimento. As demandas podem ser consideradas fatores positivos, desde que demonstradas pelos sujeitos de pesquisa ou 
detectadas pelo pesquisador. O pesquisador deve estar sensível a qualquer possibilidade de demanda, sempre, que possível, disponibilizando ajuda ao sujeito de pesquisa, como, por exemplo, atendimento psicológico para minimizar possíveis ansiedades e expectativas, atendimento médico, inserção do sujeito de pesquisa em algum programa que possa ajudá-lo e, até mesmo, dispor de tempo para poder estar ouvindo as dúvidas e a inquietude do sujeito da pesquisa.

Outra circunstância que deverá sempre ser considerada é no caso da pesquisa descobrir informações sobre a saúde e segurança de indivíduos ou populações, não podendo esta informação ser negada ao sujeito em estudo que poderá ser significantemente afetado. (BEAUCHAMP et al 1991)

Vejamos este outro exemplo de uma pesquisa, publicada em 1996, referente a estudo sobre um programa comunitário de hemoglobinopatias hereditárias em população estudantil brasileira, realizada com estudantes. Retiramos o seguinte relato dos pesquisadores: "Os resultados dos exames foram encaminhados aos estudantes segundo três possibilidades: a resultados normais em todos os exames. $B$ - alterações hematológicas... os estudantes neste caso, foram encaminhado ao Núcleo (...) e C heteogigotos para hemoglobinopatias. Os pais ou responsáveis pelo estudante foram convidados para orientação genética, sendo esta fornecida de forma didática, utilizando-se sempre, entre outros recursos, uma linguagem apropriada ao nível cultural de cada orientado. Posteriormente, os mesmos foram convidados a realizar (....) exames de toda a família gratuitamente. Após a execução dos mesmos, na entrega dos resultados foram distribuídos folhetos explicativos sobre o traço de hemoglobinopatia em questão. (340)

O sujeito da pesquisa ao disponibilizar seu tempo voluntariamente, concordando em participar do estudo, deverá ser respeitado em seu direito de receber os benefícios da pesquisa, sejam eles diretos, através de 
tratamentos, informações, participações de programas, dentre outros, bem como indiretos, publicações e disseminação a nível coletivo de informações adquiridas com o resultado da pesquisa.

\subsection{Retorno da Pesquisa: Institucional e Social}

Em estudo longitudinal da população materno-infantil da região urbana do sul do Brasil, 1993: aspectos metodológicos e resultados preliminares, realizada com todas as mulheres que tiveram filhos, encontramos um relato exemplar de como se deve retornar uma pesquisa: "Os hospitais envolvidos no estudo receberam o retorno das informações referentes aos nascimentos ali ocorridos, assim como, os indicadores globais para toda a cidade. Este retorno propiciou reflexões sobre o atendimento oferecido ao parto e ao recém-nascido nos hospitais de Pelotas, servindo como referencial para melhorias nos serviços de saúde. Os resultados do estudo estão também sendo retornados para a população geral através de uma série de artigos na imprensa local." (323)

Concordamos que muitas vezes o retorno poderá acarretar maior dispêndio financeiro e de tempo para os pesquisadores, mas com certeza trará maior interesse ao estudo efetuado e promoverá maior confiabilidade dos sujeitos estudados e da população como um todo.

A esse respeito citamos pesquisa desenvolvida para controle integrado do vetor da filariose com participação comunitária, em uma área urbana do Recife, Brasil. Esta pesquisa foi desenvolvida em todas as residências das duas áreas de estudo, que foram áreas rurais do Recife: "No projeto desenvolvido no Coque/Recife a escola mostrou ser um excelente espaço para a divulgação de conhecimento básicos sobre o vetor e a relação vetor-doença, pré-requisito para o engajamento da comunidade no controle do vetor. O trabalho desenvolvido pelos vigilantes de vetores trouxe uma contribuição efetiva à aplicação das medidas de controle do vetor e à 
transmissão de conhecimentos aos habitantes da área e permitir-lhe participar, como cidadãos, na busca de soluções para um problema da comunidade." (561)

Concordamos com BEAUCHAMP et al (1991), quando afirmam que os pesquisadores deverão se esforçar para comunicar as informações do estudo aos sujeitos e à população que foi a amostra estudada.

CIOMS (1991) afirma que estudos devem ser elaborados para obter conhecimentos que beneficiem a classe de pessoas dos quais os sujeitos de pesquisa são representativos. Consideramos importante que pesquisadores se esforcem para retornar de alguma forma os resultados das pesquisas, tanto individualmente quanto coletivamente.

Neste momento, mostraremos relatos, através dos quais analisaremos o "possível" retorno da pesquisa. Todavia, em nenhum momento, consideramos que estas pesquisas não tiveram seus resultados retornados aos sujeitos estudados. Artigos científicos, muitas vezes, trazem informações limitadas sobre a pesquisa, tornando difícil considerar a abrangência da ação do pesquisador.

Em estudo, publicado em 1994, sobre antropometria e dietética de nadadores competitivos de áreas metropolitanas da região sudeste do Brasil, realizado com atletas do sexo masculino e feminino encontramos: "Uma dieta bem balanceada pode fornecer os nutrientes necessários aos atletas, dispensando-se suplementação medicamentosa, a qual deve ser restringida apenas aos atletas que apresentam deficiência de nutrientes com comprovação bioquímica." (222).

Em estudos efetuados com pequeno número de sujeitos de pesquisa, - pesquisador deverá se esforçar para retornar os resultados 
individualmente, ou em forma de palestras ou seminários, disponibilizando espaço para perguntas e consultas caso-a-caso.

Informações simples como a elaboração de uma dieta, lista dos alimentos que seriam melhor aproveitados por atletas, palestras sobre reeducação alimentar, valorizam a participação do sujeito de pesquisa, podendo muitas vezes, mudar rotinas e, ainda assim, fazer do sujeito de pesquisa um multiplicador de informações para familiares, parentes, amigos.

Uma pesquisa sobre infarto do miocárdio e acidente vascular cerebral associados à alta temperatura e monóxido de carbono em área metropolitana do sudeste e do Brasil. Esta pesquisa foi desenvolvida com dados secundários, o que não invalida o retorno dos resultados às instituições que autorizaram o acesso aos dados. Encontramos a seguinte citação: "Podemos recomendar que pacientes com processo arterioesclerótico, em risco de IM ou AVC, principalmente idosos, devem precaver-se de praticar exercícios e se expor ao sol em dias de altas temperaturas e altas concentrações de monóxido de carbono no ar." (172)

Em algumas pesquisas é inviável o retorno individual dos resultados principalmente, quando os dados coletados foram secundários sem que houvessem condições de identificar os sujeitos. Pode-se, nestes casos, sugerir práticas à instituição que disponibilizou os dados para o estudo, ou até mesmo a um grupo e/ou comunidade que tenha a mesma problemática, assim como elaborar programas, projetos, atendimentos diferenciados, cursos, ou até mesmo, divulgar os resultados através de subsídios de secretarias de saúde ou outros órgãos de fomento.

De pesquisa, publicada em 1993, desenvolvida para saber a associação da pressão arterial diastólica com o tempo acumulado de trabalho entre motoristas e cobradores, realizada com motoristas e cobradores de veículos coletivos urbanos da cidade de Campinas e usuários 
do Ambulatório de Saúde Ocupacional do Programa de Saúde do Trabalhador, retiramos a seguinte citação: "Sintomaticamente, os motoristas consensualmente apontam o trabalho nos veículos coletivos de transporte urbano como a pior opção que a eles se apresenta. Os motivos levantados são os mais variados nas condições de manutenção dos ônibus, implicando em grande nível de barulho produzido pelo motor e maior esforço muscular para conduzir o veículo, más condições de tráfego urbano; atritos constantes com os usuários do serviço; atritos constantes com os fiscais de terminal e chefia; horário invariavelmente exíguos a serem cumprido; descanso insuficiente dentro da jornada de trabalho; refeições realizadas fora do horário habitual e em tempo reduzo; menores salários e trabalhos em turnos." (210)

Mais uma vez, consideramos a importância de pesquisadores procurarem o órgão no qual foi desenvolvida a pesquisa, onde os profissionais da área conhecessem os resultados da pesquisa, comunicando às pessoas interessadas, fomentando discussões coletivas, desenvolvendo programas e parcerias buscando alternativas para retornar os resultados da pesquisa. Consideramos o retorno da pesquisa um dever do pesquisador e um direito do sujeito de pesquisa.

Em uma outra pesquisa, que visava estudar mudanças no padrão de alimentação da população urbana brasileira e que foi realizada através de dados secundários: "Registre-se prioridade crescente que as autoridades sanitárias brasileira deveriam consignar à relação dieta-saúde, seja implementando medidas que visem à conscientização da população para o problema, seja trabalhando junto a outros setores do governo no sentido de garantir a oferta de (e o acesso) a uma alimentação saudável." (271)

Às vezes faz-se necessário que o pesquisador responsável e os colaboradores elaborem um "marketing da pesquisa". Em sendo os resultados da pesquisa acima relatada retornados em forma de projetos e/ou 
programas de como conscientizar a população sobre padrões de alimentação, haveria um ganho geral: da instituição que autorizou a coleta dos dados, da população em geral e do pesquisador e da equipe por poderem sugerir práticas através do resultados da pesquisa.

Para finalizar nossa explanação sobre o retorno da pesquisa gostaríamos de citar a Resolução 196/96 afirma que é necessário garantir o retorno dos benefícios obtidos através das pesquisas para as pessoas e as comunidades onde as mesmas forem realizadas. Quando, no interesse da comunidade, houver benefício real em incentivar ou estimular mudanças de costumes ou comportamentos, o protocolo de pesquisa deve incluir, sempre que possível, disposições para comunicar tal benefício às pessoas e/ou comunidades. 


\section{Considerações Gerais}

Consideramos que na época da publicação dos artigos analisados (1990 - 1996), talvez não existisse entre a maior parte dos pesquisadores a preocupação em relatar a abordagem do sujeito da pesquisa, cultura esta que vem se modificando com a implantação da Resolução 196/96.

Artigos científicos muitas vezes não trazem informações que seriam mais completas se estivéssemos analisando protocolos de pesquisa. Os artigos científicos, devido a forma de publicação, contêm informações restritas, sendo muitas vezes difícil saber como foi o desenvolvimento da pesquisa. Devido a este fato, nossa pesquisa foi um "diálogo" com os artigos científicos. Procuramos mostrar em nossa análise, baseada em diretrizes da Resolução 196/96, os pontos positivos e demonstrar possíveis ações éticas nos artigos expostos,

Apesar de terem sido poucos os artigos encontrados que citavam o termo consentimento explicitamente, é importante reconhecer que a análise de artigos científicos, como já explanado acima, não disponibilizam informações completas, sendo impossível afirmar que os artigos que não constavam a palavra "consentimento" não trouxessem a ação implícita na prática dos pesquisadores.

Ressaltamos que o exercício da autonomia através do processo do consentimento deverá sempre ser considerado na prática dos pesquisadores. A autonomia é uma conquista do sujeito de pesquisa e deverá ser valorizada e respeitada no processo de solicitação do consentimento. Reforçamos esta afirmativa, citando GUIMARÃES et al (1997) que expõem que a superação das dificuldades só ocorre quando há possibilidade de diálogo, ou seja, muito embora a comunicação seja necessariamente dialógica, é preciso que se crie a corrente entre os interlocutores para que se estabeleça, de fato, a comunicação. Se esta 
corrente não se estabelecer entre pessoas diferentes, o respeito, como postulado pelos códigos de ética e diretrizes não poderá verdadeiramente refletir o reconhecimento de que, embora diferente de mim, o outro é livre, capaz de decidir sobre sua vida independentemente de sua condição social ou cultural, e merecedor de tal reconhecimento. (p.16)

Por ser a prática dos pesquisadores normalmente centrada em populações mais carentes, faz-se necessário, especial atenção na abordagem destes sujeitos. Deverão estar sensíveis com relação ao sujeito de pesquisa, grupo e/ou comunidade, avaliando as condições e, na percepção de situação de vulnerabilidade, deverão redobrar a atenção, garantindo aos sujeitos, através de informações detalhadas, condições para decidir livremente.

A garantia do anonimato da privacidade e da confidencialidade dos dados é imprescindível para que não acarrete riscos de danos psicológicos, morais e sociais aos sujeitos estudados. Uma informação confidencial revelada, uma publicação citando local de desenvolvimento ou nomes, o uso da imagem de sujeitos sem tomar as devidas precauções, como colocar uma tarja nos olhos, pode comprometer indivíduos, grupos e/ou comunidades.

O retorno da pesquisa é outro fator imprescindível e que deveria ser considerado como uma obrigatoriedade para o desenvolvimento da pesquisa. De que adianta desenvolver pesquisas, dispor de financiamentos, tempo, trabalho físico e intelectual, se não houver o benefício do retorno da pesquisa, mesmo na impossibilidade de um retorno prático, em forma de programas, projetos, atendimentos, cursos, seminários. Por isso, é importante que pesquisadores publiquem suas pesquisas, pois os resultados podem trazer grande contribuições para outros pesquisadores.

Como anteriormente relatado, ressaltamos que a prática ética da pesquisa pode ser trabalhosa. Verificamos que são muitas as ações para 
desencadear uma prática correta e justa. Por outro lado, consideramos que estas condutas já são intrínsecas ao papel de cidadão do pesquisador. Sugerimos a leitura dos documentos que abordam o tema principalmente a Resolução 196/96, importante normalização da ética em pesquisa no Brasil, cuja efetividade já está assegurada.

Finalizando não é demais ressaltar que a implantação da Resolução 196/96, em 10 de outubro de 1996, vem trazendo mudanças significativas para a prática de pesquisas no Brasil. A criação de Comitês de Ética em Pesquisa e o interesse de pesquisadores de várias áreas, o reconhecimento das agências de fomento e dos periódicos de diversas áreas vêm se consolidando a cada dia. Nossa sugestão é que se efetuem estudos posteriores a 1996 para verificar o impacto da Resolução 196/96. 


\section{Referências Bibliográficas}

A Report of the Royal College of Physicians of London. Guideklines on the practice of ethics committees in medical research involving human subjects. $3^{a}$ ed. Londres: The Royal College of Physicians of London; 1996.

Angell M. The ethics of clinical research in the third world [editorials]. The New England Journal of Medicine 1997; 337(12): 847-849.

As áreas temáticas especiais. Cadernos de ética em pesquisa. 1998; 1(1): 9-10.

Beauchamp TL, Childress JF. Principles of biomedical ethics. $3^{\mathrm{a}}$ ed. Oxford: Oxford University Press, 1989.

Beauchamp TL et col. Ethical guidelines for epidemiologists. Journal Clinical Epidemiology. 1991; 44 Suppl 1: 151S-169S.

Beecher HK. Ethics and clinical research. The New England Journal of Medicine. 1966; 274(24): 1354-1360.

Brasil. Estatuto da Criança e do Adolescente. $1^{\text {a }}$ ed. São Paulo: Ed. Cortez; 1991.

Brasil. Código civil. $37^{\mathrm{a}}$ ed. São Paulo: Saraiva; 1987.

Brasil. Constituição da República Federativa do Brasil. São Paulo. Editora Atlas; 1996.

[CIOMS] Consejo de Organizaciones Internacionales de las Ciências Médicas (CIOMS)/Organización Mundial de La Salud (OMS). Normas Éticas 
Internacionales para las Investigaciones Biomédicas com Sujetos Humanos. CIOMS. Washington; 1996.

[CIOMS] Council for International Organizations of Medical Sciences (ClOMS). World Health Organizations (WHO). Ethics and Epidemiology: International Guidelines. CIOMS. Geneve; 1991.

[CIOMS] Council for International Organizations of Medical Sciences (ClOMS). World Health Organizations (WHO). Ethics and Research on Human Subjects: International Guidelines. Geneve. CIOMS; 1992.

Clotet J. O consentimento informado nos comitês de ética em pesquisa e na prática médica: conceituação, origens e atualidade. Bioética. 1995; 3(1): 51-60.

Doyal L. Informed consent in medical research: Journal should not publish research to which patients have not given fully informed consent - with three exceptions [Education and debate]. BMJ. 1997; 314: 1107-1111.

Fortes PAC. Ética e Saúde: Questões éticas, deontológicas e legais, tomada de decisões, autonomia e direitos do paciente, estudos de caso. São Paulo: EPU; 1998. p. 105-19.

Fortes PAC. Reflexões sobre a bioética e o consentimento esclarecido. Bioética. 1994; 2: 129-135.

Fortes PAC, Sacardo DP. Ética na assistência à saúde do adolescente e do joven. In. Ministério da Saúde. Cadernos juventude, saúde e desenvolvimento. Brasília: Ministério da Saúde; 1999; 147-161.

Forattini OP. Pesquisa em saúde pública. Revista de saúde pública. 1995; 29(2): 81-8. 
Francisconi CF, Goldin JR. Aspectos bioéticos da confidencialidade e privacidade. In: Conselho Federal de Medicina. Iniciação à Bioética. Brasília: Conselho Federal de Medicina; 1998. p. 269-284.

Freitas CBD, Hoosne WS. Pesquisa com seres humanos. In: Conselho Federal de Medicina. Iniciação à Bioética. Brasília: Conselho Federal de Medicina; 1998. p. 193-204.

Freund PA. Ethical problems in human experimentation. The New England Journal of Medicine. 1965; 273(13): 687-692.

Gil AC. Métodos e Técnicas de Pesquisa Social. São Paulo. Atlas; 1994. P. 43.

Glanz K, Rimer BK, Lerman C. Ethical issues in the design and conduct of community-based. In: Coughlin SS, Beauchamp TL. Ethics and epidemiology. New York: Oxford University Press; 1996. p. 156-177.

Gold EB. Confidenciality and privacy protection in epidemiologic research. In: Coughlin SS, Beauchamp TL. Ethics and epidemiology. New York: Oxford University Press; 1996. p. 128-144.

Grecco DB. A ética dos ensaios clínicos e a nova versão da Declaração de Helsinque: A pressão para as mudanças e os riscos. [Etifiocr.100.c e 37]

Guimarães MCS, Novaes SC. Autonomia reduzida e vulnerabilidade: Liberdade de decisão, diferença e desigualdade. Bioética. 1999; 7: 21-24.

Guimarães MCS, Spink MJP, Antunes MAM. Do respeito à compreensão das diferenças: um olhar sobre a autonomia. Bioética. 1997; 5: 13-17. 
Hahn RA. Ethical Issues. In: Teutsch SM, Churchill RE. Principles and Practice of Public Health Surveillance. Oxford: Oxford University Press; 1994. 175-189.

Hood CA, HOPE T, DOVE P. Videos, photographs, and patients consent [education and debate]. British Medical Journal. 1998; 316 (7136): 10091011.

Hossne WS. Vieira S. A Ética e a Metodologia. São Paulo. Pioneira; 1998, p. 99-100.

Hossne WS. Vieira S. Experimentação com Seres Humanos: Aspectos Éticos. In. Segre M. Cohen C. Bioética. São Paulo: EDUSP; 1995. p. 127146.

Ingelfinger FJ. Informed (but uneducated) consent [editorial]. The New England Journal of Medicine. 1972; 287(9): 465-466.

Kelly RJ, Fluss SS, Gutteridge. The regulation of research on human subjects: a decade of progress. CIOMS. Ethics and reseach on human subjects: international guidelines. Geneve: CIOMS; 1993. p. 127-166.

Kennedy I. Grubb A. Medical Law: Text and Materials. London. Buttweworth; 1989. p. 847-69.

Last J. Professional standards of conduct for epidemiologists. In: Coughlin SS, Beaachamp TL. Ethics and epidemiology. New York: Oxford University Press; 1996. p. 53-75.

Last JM. Epidemiology and Ethics. In: CIOMS. Ethics and Epidemiology. Geneve. CIOMS; 1991. p.8-13. 
Lavertu DS, Linares Am. Ethical principles of biomedical research on human subjects: their application and limitations in Latin American and the caribbean. In: Pan American Health Organization. Bioethics: issues and perspectives. Washington: PAHO; 1997. p. 107-118.

Leikin S. Ethical issues in epidemiologic research with children. In: Coughlin SS, Beauchamp TL. Ethics and epidemiology. New York: Oxford University Press; 1996. p. 53-75.

Levine RJ. Ethics and regulation of clinical research. $2^{\mathrm{a}}$ ed. New Haven: Yale University Press, 1986.

Mariner WK. Distinguishing "exploitable" from "vulnerable" populations: when consent is not the issue. In. CIOMS. Ethics and reseach on human subjects: international guidelines. Geneve: CIOMS; 1993. p. 44-55.

McCarthy CR. Experiences with Boards and Comissions Concerned with Research Ethics in the United Sattes. In: Berg K., Tranoy KE. Research Ethics. New York (NY): Alan K. Liss, Inc; 1982. p. 111-22.

McCarthy CR. Confidenciality: the protection of personal data in epidemiological and clinical research trials. In: CIOMS. Ethics and epidemiology: International guidelines. Geneva: CIOMS; 1991. p. 59-63.

Ministério da Saúde/Conselho Nacional de Saúde. Diretrizes e Normas Regulamentadoras de Pesquisa envolvendo Seres Humanos. Brasília; 1996.

Ministérios da Saúde/Conselho Nacional de Saúde. Resolução 01/88. Bioética 1995; São Paulo: EDUSP. p. 137-54. 
Ministério da Saúde/Conselho Nacional de Saúde. Resolução 251/97. In Hossne WS, Vieira S. A ética e a metodologia. São Paulo: Pioneira; 1998.

Muñoz DR, Fortes PAC. O princípio da autonomia e o consentimento livre e esclarecido. In: Conselho Federal de Medicina. Iniciação à Bioética. Brasília: Conselho Federal de Medicina; 1998. p. 53-70.

National Bioethics Advisory Commission. Ethical and policy issues in international research. Bethesda: National Bioethics Advisory Commission. 2000.

National Bioethics Advisory Commission. Research involving persons with mental disorders that may affect decisionmaking capacity. Volume 1. Rockville: National Bioethics Advisory Commission; 1998.

[NHMRC] National Health and Medical Research Council. statement on human experimentation and supplementary notes. Austrália: Australian Government Publishing Service. 1992.

[NCBHR] National Council on Bioethics in Human Research. Reflections on research involving children. Canada: National Council on Bioethics in Human Research with the support of the Canadian Paediatric Society; 1993.

Neves M do CP. A bioética e sua evolução. O Mundo da Saúde. 2000; 24(24): 211-225.

Nuffield Council on Bioethics. The ethics of clinical research in developing countries. London: Nufield Council on Bioethics; 1999.

Osuntokun BO. A perspective of Developing countries. In: CIOMS. Ethics and research on human subjects: International guidelines. Geneve: CIOMS; 1993. p. 25-35. 
Pearson SD, Dabi JE, Emanuel EJ. Ethical guidelines for physician compensation based on capitation [sounding board]. The New England Journal of Medicine 1998; 339(10): 689-693.

Pessine L, Barchifontaine. Problemas atuais de bioética. $4^{\mathrm{a}}$ ed. São Paulo: Edições Loyola, 1997.

Porter JP. Ethical issues related to nutrition field trials. Food and Nutrition Bulletin. 1989; 11(3): 36-40.

Scutifield \& Keck... checar

Segre M, Cohen C. Definição de valores, moral, eticidade e ética. Bioética. São Paulo: EDUSP; 1995. p. 13-22.

Segre M, Silva FL e, Schramm FR. Contexto histórico, semântico e filosófico do princípio da autonomia. Bioética. 1998; 6: 15-23.

Senado Federal. Lei no. 8.842, de 4 de janeiro de 1994 [on line]. http://wwwt.senado.gov.br. Brasília: 1994.

Sheps MC. Ridley JC. Public Health and Population Change: Current Research Issues. Pittsburgh: University of Pittsburgh Press; 1964.

Soldati VR. Ética em pesquisas da saúde. Algumas reflexões. In: AngeramiCamon VA (Org.). A ética na saúde. São Paulo: Pioneira; 1997. p. 31-46.

Stevenson et Col. Ethical issues and approches in AIDS research. In. Ostrow DG. Kessler RC. Methodological issues in AIDS behavioral research. New York: Plenum Press; 1993. p. 19-49. 
Sweemer-Ba $\mathrm{C}$ de. Protecting the vulnerable. In: CIOMS. Ethics and research on human subjects: International guidelines. Geneve: CIOMS; 1993. p. $44-55$

Triviños ANS. Introdução à pesquisa em ciências sociais: A pesquisa qualitativa em educação. $1^{a}$ ed. São Paulo: Editora Atlas S.A., 1987.

UNAIDS Guidance Document. Ethical considerations in HIV preventive vaccine research. 2000 .

U.S. Department of Health, Education, and Welfare. Belmont Report [on line] http://www.med.umich.edu/irbmed/ethics/belmont/BELMONTR.HTM (São Paulo, 19/02/1999).

Vieira S, Hoosne WS. Experimentação com seres humanos. $1^{\text {a }}$ ed. São Paulo: Editora Moderna. 1987.

Wettstein RM. Competence. [article on CD ROM]. Encyclopaedia of Bioethics. 2nd ed. Version 2.0. New York: Wesleyan University Press; 1995.

Willner et col.

World Medical Association. Declaration of Helsinki: Ethical principles for medical research involving human subjects. [on line] http://www.wma.net. 2000. 
ANEXO 1 


\section{INSTRUMENTO DE COLETA DE DADOS}

Nome da Revista:

Nome do Artigo:

Período de

Publicação:

Ano:

Paginação:

1) $O$ artigo envolve seres humanos?
( ) $\operatorname{Sim}$
( ) Não

2) Se a resposta for "Sim", qual a forma?

( ) Participação direta individual

( ) Participação direta Coletivamente (grupos e/ou comunidades)

( ) Participação indireta (manejo de informações, dados secundários, material biológico)

( ) Participação direta e indireta (coleta de dados secundários e abordagem direta ao Sujeito da pesquisa

( ) Outras - especificar:

3) Tipo de Instituição
( ) Saúde
( ) Educação
( ) Assistência Social
( ) Lazer
( ) Instituições de Reabilitação
( ) Associações Religiosas
( ) Empresas, indústrias, escritórios, órgãos públicos
( ) Comunidades diversas
( ) Outras - especificar:

4) Tipologia mínima da pesquisa:
( ) Biológica
( ) Ambiental
( ) Genética Humana
( ) Psicológica
( ) Nutricional
( ) Reprodução Humana
( ) Social
( ) Educacional
( ) Epidemiológica
( ) Econômica
( ) Farmacológica
( ) Outras - especificar:
( ) Clínica e/ou cirúrgica 


\section{CATEGORIAS DE ANÁLISE}

"O respeito devido à dignidade humana exige que toda pesquisa se processe após consentimento livre e esclarecido dos sujeitos, indivíduos ou grupos que por si e/ou por seus representantes legais manifestem a anuência à participação na pesquisa"

"a liberdade do consentimento deverá ser particularmente garantida para aqueles sujeitos que, embora adultos e capazes, estejam, expostos a condicionamentos específicos ou à influência de autoridade, especialmente estudantes, militares, empregados, presidiários, internos, centros de readaptação, casas-abrigo, asilos, associações religiosas e semelhantes, assegurando-Ihes a inteira liberdade de participar ou não da pesquisa sem quaisquer represálias."

"Em comunidades culturalmente diferenciadas, inclusive indígenas, deve-se contar com a anuência antecipada da comunidade através dos seus próprios líderes, não se dispensando, porém, esforços no sentindo do consentimento individual."

"Garantir que as pesquisas em comunidades, sempre que possível, traduzir-se-ão em benefícios cujos efeitos continuem a se fazer sentir após sua conclusão. $O$ projeto deve analisar as necessidades de cada um dos membros da comunidade e analisar as diferenças presentes entre eles, explicitando como será assegurado o respeito às mesmas."

"Prever procedimentos que assegurem a confidencialidade e a privacidade, a proteção da imagem e a não estigmatização, garantindo a não utilização das informações em prejuízo das pessoas e/ou comunidades, inclusive em termos de auto-estima, de prestígio e/ou econômico financeiro."

Outras categorias éticas pertinentes: 
ANEXO 2 


\section{REFERÊNCIA BIBLIOGRÁFICA POR ORDEM NUMÉRICA DOS ARTIGOS CIENTÍFICOS UTILIZADOS PARA ANÁLISE DAS REVISTAS DE SAÚDE PÚBLICA E CADERNOS DE SAÚDE PÚBLICA, QUE ENVOLVIAM DIRETA E INDIRETAMENTE SERES HUMANOS:}

1. Favaro RMD. Vannucgi H. Níveis plasmáticos de zinco e antropometria de crianças da periferia de centro urbano no Brasil. Revista de Saúde Pública. 1990; 24(1): 5-10

14. Perez GG et col. Inquérito sorológico para a detecção de anticorpos contra o vírus da imunodeficiência humana $(\mathrm{VIH})$ em crianças internadas em enfermaria geral. Revista de Saúde Pública. 1990; 24(2): 113-118.

35. Niobey FML et col. Soroprevalência e fatores de risco para a infec"cão pelo vírus da hepatite $B$ pelos marcadores AgHBs e anti-HBs em prisioneiros e primodoares de sangue. Revista de Saúde Pública. 1990; 24(4): 270-276.

63. Lemme $A C$ et col. Considerações metodológicas na interpretação do rastreamento sorológico da hepatite $B$ em doadores de sangue. Revista de Saúde Pública. 1991; 25(1): 11-16

69. Macharelli CA. Oliveira LR de. A satisfação do usuário em hospital universitário. Revista de Saúde Pública. 1991; 25(1): 41-46

79. Noronha MF et col. Consumo de substâncias psicoativas entre estudantes de rede privada. Revista de Saúde Pública. 1991; 25(3): 150-156.

83. Odalis TS et col. Anemia e desnutrição maternas e sua relação com o peso ao nascer. Revista de Saúde Pública. 1991; 25(3) 193-194. 
87. Gir E et col. Doenças sexualmente transmissíveis: conceitos, atitudes e percepções entre coletores de lixo. Revista de Saúde Pública. 1991; 25(3): 226-229.

120. Waib PH et col. Avaliação da ingestão dietética de cálcio em indivíduos adultos portadores de hipertensão arterial idiopática. Revista de Saúde Pública. 1992; 26(1): 27-33.

131. Passos ADC et col. Prevalência de marcadores sorológicos de hepatite B numa pequena comunidade rural do Estados de São Paulo. Revista de Saúde Pública. 1992; 26(2): 119-124.

136. Cardoso MA et col. Anemia em população de área endêmica de malária, Rondônia (Brasil). Revista de Saúde Pública. 1992; 26(3): 161-166.

153. Koizumi MS et col. Padrão das lesões nas vítimas de acidentes de motocicleta. Revista de Saúde Pública. 1992; 26(5): 306-315.

166. Santos UP et col. Síndrome dos edifícios doentes em bancários. Revista de Saúde Pública. 1992; 26(6): 400-404.

172. Rumel D. Infarto do miocárdio e acidente vascular cerebral associados à alta temperatura e monóxido de carbono em área metropolitana do sudeste do Brasil. Revista de Saúde Pública. 1993; 27(1): 15-22.

173. Paiva e Silva RB de et col. A anemia falciforme como problema de saúde pública no Brasil. Revista de Saúde Pública. 1993; 27(1): 54-8.

178. Paiva e Silva RB de et al. A anemia falciforme como problema de saúde pública no Brasil. 1993; 27(1): 54-8. 
181. Ramos $L R$ et col. Perfil do idoso em área metropolitana na região sudeste do Brasil: resultados de inquérito domiciliar. Revista de Saúde Pública. 1993; 27(2): 87-94.

183. Halal IS. Determinantes do hábito de fumar e de seu abandono durante a gestação em localidade urbana na região sul do Brasil. Revista de Saúde Pública. 1993; 27(2); 105-12.

210. Cordeiro $R$ et col. Associação da pressão arterial diastólica com o tempo acumulado de trabalho entre motoristas e cobradores. Revista de Saúde Pública. 1993; 27(5): 363-372.

219. Grumucah AS et col. Nutritional factors in milk from Brazilian mother delivering small for gestational age neonates. Revista de Saúde Pública. 1993; 27(6): 455-462.

221. Martins SJ. Menezes RC. Evolução do estado nutricional de menores de 5 anos em aldeias indígenas da tribo Parakanã, na Amazônia oriental brasileira. Revista de Saúde Pública. 1994; 28(1): 18.

222. Soares EA et col. Estudo antropométrico e dietético de nadadores competitivos de áreas metropolitanas da região sudeste do Brasil. Revista de Saúde Pública. 1994; 28(1): 9-19.

226. Bitar $M L$ et col. Caracterização da saúde de crianças atendidas em creches e prevenção dos distúrbios da comunicação. Revista de Saúde Pública. 1994; 28(1): 46-58.

249. Barros FC. Promoção da amamentação em localidade urbana da região sul do Brasil: estudo de intervenção randomizado. Revista de Saúde Pública. 1994; 28(4); 277-283. 
268. Torres MAA et col. Terapêutica com doses profiláticas de sulfato ferroso como medida de intervenção no combate à carência de ferro em crianças atendidas em unidades básicas de saúde. Revista de Saúde Pública. 1994; 28(6): 410-5.

271. Mondini L. Monteiro CA. Mudanças no padrão de alimentação da população urbana brasileira. Revista de Saúde Pública. 1994; 28(6): 433-9.

279. Moreira LB et col. Prevalência de tabagismo e fatores associados em área metropolitana da região sul do Brasil. Revista de Saúde Pública. 1995; 29(1): 46-51.

304. Prado $\mathrm{M}$ de $\mathrm{S}$ et col. Hipovitaminose $\mathrm{A}$ em crianças de áreas rurais de semi-árido baiano. Revista de Saúde Pública. 1995; 29(4): 295-300.

310. Botega NJ et col. Transtorno do humor em enfermaria de clínica médica e validação de escala de medida (HAD). Revista de Saúde Pública. 1995; 29(5): 355-63.

319. Santos LMP et al. Situação nutricional e alimentar de pré-escolares no semi-árido da Bahia (Brasil): I. Avaliação antropométrica. Revista de Saúde Pública. 1995; 29(6): 463-71.

321. Fonseca $W$ et col. Determinantes do aborto provocado entre mulheres admitidas em hospitais em localidade da região nordeste do Brasil. Revista de Saúde Pública. 1996; 30(1): 13-8.

323. Victora, $C G$ et al. Estudo longitudinal da população materno-infantil da região urbana do sul do Brasil. Revista de Saúde Pública. 1993: Aspectos metodológicos e resultados preliminares. 1996; 30(1); 34-45. 
340. Compri MB et col. Programa comunitário de hemoglobinopatias hereditárias em população estudantil brasileira. Revista de Saúde Pública. 1996; 30(2): 187-95.

341. Shirakawa I et col. Family expectation, social adjustment and gender: differences in a sample of schizophrenic patients. Revista de Saúde Pública. 1996; 30(3): 205-12.

369. Osis MJD et col. Dificuldades para obter informações da população de mulheres sobre o aborto legal. Revista de Saúde Pública. 1996; 30(5): 444-451.

372. Moraes SA, Souza JMP de. Efeito dose-resposta de fatores de risco para a doença isquêmica do coração. Revista de Saúde Pública.1996; 30(5): 471-8.

401. Andrade SMO de. Opinião sobre AIDS e possíveis mudanças de comportamento de heterossexuais masculinos. Cadernos de Saúde Pública. 1991; 7(1): 45-68.

451. Rangel ML. Saúde do trabalhador - identidade dos sujeitos e representações dos riscos à saúde na indústria petroquímica. Cadernos de Saúde Pública. 1993; 9(3): 333-48.

471. Davoli A et col. Prevalência de violência física relatada contra crianças em uma população de ambulatório psiquiátrico. Cadernos de Saúde Pública. 1996; 10(1): 92-98.

492. Gonçalves CMR et col. Prevalência de hipovitaminose A em crianças da periferia do município de Campinas, São Paulo, Brasil. Cadernos de Saúde Pública. 1995; 11(1): 85-96. 
493. Costa RG et col. A decisão de abortar: processo e sentimentos envolvidos. Cadernos de Saúde Pública. 1995; 11(1): 97-105

498. Klein $\mathrm{CH}$ et col. Hipertensão arterial na llha do Governador. Rio de Janeiro, Brasil. I. Metodologia. Cadernos de Saúde Pública. 1995; 11(2): 187-201.

500. Santos $E$ de $O$ et al. Diagnóstico das condições de saúde de uma comunidade garimpeira na Região do Rio Tapajós, Itaituba, Pará, Brazil. Cadernos de Saúde Pública. 1995; 11(2): 212-225.

517. Merchan H. Grau de informação, atitudes e representações sobre o risco e a prevenção de AIDS em adolescentes pobres do Rio de Janeiro, Brasil. Cadernos de Saúde Pública. 1995; 11(3): 463-479.

530. Garcia-Montrone V. Rose JC de. Uma experiência educacional de incentivo ao aleitamento materno estimulado do bebê, para mães de nível sócio-econômico baixo: Estudo preliminar. Cadernos de Saúde Pública. 1996; 12(1): 61-8.

552. Dias da Costa JS et col. Prevalência do uso de métodos contraceptivos e adequação do uso de anticoncepcionais orais na cidade de Pelotas, Rio Grande do Sul, Brasil. Cadernos de Saúde Pública. 1996; 12(3): 339-344.

556. Macedo LM de C. Rey L. Enteriparasitoses em gestantes e puérperas no Rio de Janeiro. Cadernos de Saúde Pública. 1996; 12(3): 383-8.

561. Régis $L$ et al. Controle integrado do vetor da filariose com participação comunitária, em uma área urbana do Recife, Brasil. Cadernos de Saúde Pública. 1994; 12(4): 473.482 
564. Kakietzief Z. Identificando barreiras para aderência ao tratamento de hanseníase. Cadernos de Saúde Pública. 1996; 12(4): 497-505.

565. Oliveira HMV et col. Situação epidemiológica da tuberculose infantil no município do Rio de Janeiro. Cadernos de Saúde Pública. 1996; 12(4): 507-513. 